\title{
XPG: a multitasking genome caretaker
}

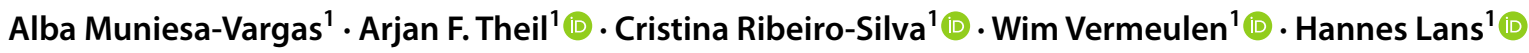

Received: 26 November 2021 / Revised: 27 January 2022 / Accepted: 5 February 2022 / Published online: 1 March 2022

(c) The Author(s) 2022

\begin{abstract}
The XPG/ERCC5 endonuclease was originally identified as the causative gene for Xeroderma Pigmentosum complementation group G. Ever since its discovery, in depth biochemical, structural and cell biological studies have provided detailed mechanistic insight into its function in excising DNA damage in nucleotide excision repair, together with the ERCC1-XPF endonuclease. In recent years, it has become evident that XPG has additional important roles in genome maintenance that are independent of its function in NER, as XPG has been implicated in protecting replication forks by promoting homologous recombination as well as in resolving R-loops. Here, we provide an overview of the multitasking of XPG in genome maintenance, by describing in detail how its activity in NER is regulated and the evidence that points to important functions outside of NER. Furthermore, we present the various disease phenotypes associated with inherited XPG deficiency and discuss current ideas on how XPG deficiency leads to these different types of disease.
\end{abstract}

Keywords DNA damage response $\cdot$ XPG/ERCC $5 \cdot$ Structure $\cdot$ NER $\cdot$ Xeroderma pigmentosum-Cockayne syndrome

\section{Introduction}

DNA lesions are an unavoidable fact of life and it is estimated that, daily, each of our cells is confronted with approximately $10^{4}-10^{5}$ new DNA lesions $[1,2]$. These lesions can interfere with essential genome processes, such as transcription and replication, and thus have immediate and long-term consequences. Cells, therefore, utilize a range of specialized DNA repair mechanisms, signaling pathways, tolerance processes and cell cycle checkpoints, collectively called the DNA damage response (DDR), to cope with DNA lesions and maintain proper function of the genome $[1,3$, 4]. Genetic diseases, neurological degeneration, premature aging and increased cancer susceptibility are severe fallouts of inherited DDR defects that illustrate the human's health reliance on an operational DDR. XPG, also called ERCC5, is a major DDR endonuclease, whose deficiency results in severe developmental defects, progeria and cancer. It is mainly known for its role in excising DNA damage in nucleotide excision repair (NER), but in recent years, it

Hannes Lans

w.lans@erasmusmc.nl

1 Department of Molecular Genetics, Erasmus MC Cancer Institute, Oncode Institute, Erasmus University Medical Center, Rotterdam, The Netherlands has been found to function in other genome maintenance mechanisms as well. In this review, we provide a detailed overview of XPG's function and activity in NER, highlighting recent new insights, discuss the evidence suggesting that it has important functions beyond NER and describe the pleiotropic phenotypic consequences of inherited XPG deficiency.

\section{Nucleotide excision repair}

NER is unique in its ability to repair a wide range of lesions that arise from diverse and different genotoxic insults because, in contrast to most other DNA repair pathways, it detects the structural consequences of DNA damage, i.e., helix destabilization, instead of the DNA lesion itself [5]. These helix-distorting lesions include the UV-induced cyclobutane pyrimidine dimers (CPDs) and pyrimidine-pyrimidone (6-4) photoproducts (6-4PPs), ROS-induced cyclopurines and chemotherapy druginduced (e.g., cisplatin) intrastrand crosslinks. More than 30 proteins are involved in the intricate network of NER, and cooperate to perform four essential steps: (1) damage detection; (2) damage verification; (3) excision of a singlestranded damage-containing DNA segment; and (4) DNA synthesis and ligation to restore and seal the gap $[6,7]$ 

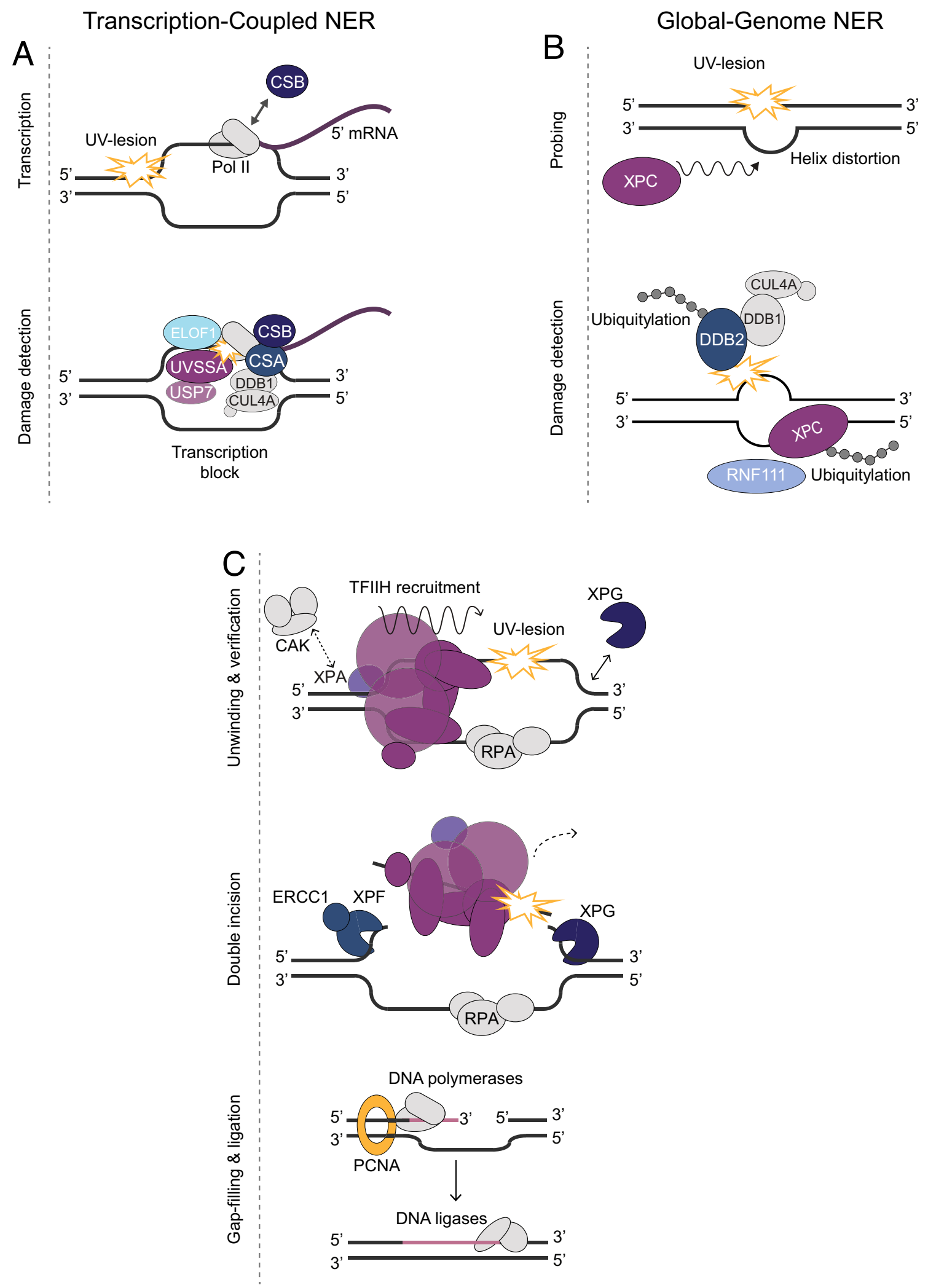

(Fig. 1). Depending on where in the genome lesions occur, two different damage detection sub-pathways can initiate NER. Transcription-coupled repair (TC-NER) detects lesions in the transcribed strand of active genes, whereas global genome repair (GG-NER) detects lesions anywhere in the genome. 
4Fig. 1 Nucleotide excision repair mechanism. A Transcription-coupled NER. Pol II stalling at UV lesions recruits CSB, whose prolonged binding to Pol II triggers CSA recruitment, which is part of the larger CRL4 ${ }^{\mathrm{CSA}}$ complex that also comprises DDB1, CUL4A and RBX1. CRL4 ${ }^{\mathrm{CSA}}$ interacts with ELOF1 and ubiquitylates CSB and Pol II to target these for proteasomal degradation. Next, UVSSA and USP7 are recruited, which, respectively, recruit TFIIH and de-ubiquitylate and stabilize CSB. B Global genome NER. DDB2, as part of the CRL4 ${ }^{\mathrm{DDB} 2}$ complex, binds to UV lesions and facilitates their efficient recognition and stable binding by XPC, by means of autoubiquitylation and XPC ubiquitylation. Stable binding of XPC leads to TFIIH recruitment, followed by RNF111-mediated ubiquitylation and dissociation of XPC. C Core NER reaction. Stable association of XPC or UVSSA to lesions recruits TFIIH, which unwinds the DNA with its helicase activity to verify the damage. XPA displaces the TFIIH CAK subcomplex and stimulates its helicase activity. RPA binds the undamaged strand and together with XPA positions the ERCC1-XPF and XPG endonucleases 5' and $3^{\prime}$ to the lesion, respectively. XPF $5^{\prime}$ incision is followed by XPG $3^{\prime}$ incision after which PCNA and DNA polymerases, together with other re-synthesis factors, are recruited to fill the gap

The great majority of helix-destabilizing DNA lesions are detected by GG-NER, which examines the entire genome, coding and non-coding, for DNA damage-induced helical distortions $[6,7]$. The XPC protein, as part of the heterotrimeric XPC-CETN2-RAD23B complex is capable of detecting a broad range of structurally unrelated lesions by employing an indirect damage recognition mode with which it probes for DNA helix destabilization [5, 8, 9]. XPC requires the auxiliary function of the $\mathrm{CRL} 4{ }^{\mathrm{DDB} 2} \mathrm{E} 3$ ubiquitin ligase complex, comprising DDB1, DDB2, CUL4A and $\mathrm{RBX} 1$, to efficiently recognize some types of lesions, such as the UV-induced CPDs $[10,11]$. CRL $4^{\mathrm{DDB} 2}$ stimulates XPC recruitment by binding and flipping out damaged bases, making them more suitable substrates for XPC, and by ubiquitylating both DDB2 and XPC, promoting the DNA damage handover [10-14]. To counteract the cytotoxic effects of lesions that block RNA Polymerase II (Pol II) forward translocation during transcription elongation, TC-NER is activated with the recruitment of CSB and CSA proteins [15, 16]. CSB transiently interacts with Pol II, but binds more stably when it cannot push Pol II forward due to a transcription-blocking lesion [17]. This leads to recruitment of CSA, which is part of the larger E3 ubiquitin ligase CRL4 ${ }^{\mathrm{CSA}}$ and directs the ubiquitylation and proteasomal degradation of CSB and, after interacting with ELOF1, of Pol II [18-22]. CSB is, however, stabilized by subsequent recruitment of the UVSSA protein together with the de-ubiquitylation enzyme USP7 [23-25].

Stable DNA damage association of XPC, in GG-NER, or UVSSA, in TC-NER, leads to the next step of damage verification by the NER machinery through recruitment of TFIIH, which directly interacts with either XPC (via GG-NER) or UVSSA (via TC-NER) [26-28]. TFIIH is a 10-subunit multifunctional complex that opens the DNA helix in both NER
[29] and transcription initiation by Pol II [30]. Its XPD helicase subunit verifies the presence of genuine NER substrates by unwinding the DNA in 5'-3' direction while scanning for helicase-blocking lesions [29, 31]. This helicase activity and damage verification is stimulated by the association of the DNA damage binding protein XPA [31-33], which also, together with the single-stranded DNA-binding factor RPA, orients the two structure-specific endonucleases ERCC1-XPF and XPG on the damaged strand [34-36]. The presence of XPG enables the first incision, $5^{\prime}$ to the lesion, by ERCC1-XPF, and the second incision, $3^{\prime}$ to the lesion and leading to damage excision, is then finalized by XPG itself [36]. The resulting 22-30 nucleotide DNA gap is filled by novel DNA synthesis involving the activity of replication proteins RFC, PCNA and either DNA polymerase $\delta$ (non-replicating cells), $\varepsilon$ (mainly in replicating cells) or $\kappa$ (non-replicating cells) and either DNA ligase I or III to seal the gap [37-39].

\section{XPG activity in nucleotide excision repair}

$\mathrm{XPG}$ is a member of the XPG/RAD2 family of structurespecific nucleases, which in mammals also includes FEN1, GEN1 and EXO1 and which all have important genome maintenance functions [40]. FEN1 participates in DNA replication by cleaving 5 ' single and double flap structures [41]. GEN1 functions in resolution of double holiday junctions during various types of homologous recombination [42]. EXO1 resects DNA in multiple genome maintenance mechanisms, including mismatch repair, double-strand break repair and NER [43]. XPG is an endonuclease that was found to cut $5^{\prime}$ flap structures, $5^{\prime}$ single-stranded tails of splayed-arm structures and to incise bubble DNA at the 3' junction in vitro [44, 45] (Fig. 2a). This activity implies that during NER, XPG incises DNA at the 3 ' site of the lesion. Indeed, incision of XPG during NER requires a bubble substrate [46], which is generated by the helicase activity of TFIIH [47, 48]. As XPG interacts with DNA at ss/dsDNA junctions [49], XPG is likely only stably bound to damaged DNA in vivo once this bubble is created, i.e., simultaneously with or after TFIIH recruitment and activity. Indeed, its recruitment and stable binding to DNA damage in living cells was shown to depend on functional TFIIH and to be temperature sensitive, in line with a role for TFIIH helicase activity to unwind DNA [35]. The TFIIH-dependent recruitment of XPG furthermore correlates with the strong observed interaction between XPG and TFIIH, even in the absence of DNA damage, suggesting that at least a fraction of XPG is always bound to TFIIH and stabilizes it [50, 51]. Besides, XPG has been reported to interact directly with RPA [52], which also stimulates its incision activity in vitro [53]. As RPA binds the undamaged ssDNA opposite of the 
A
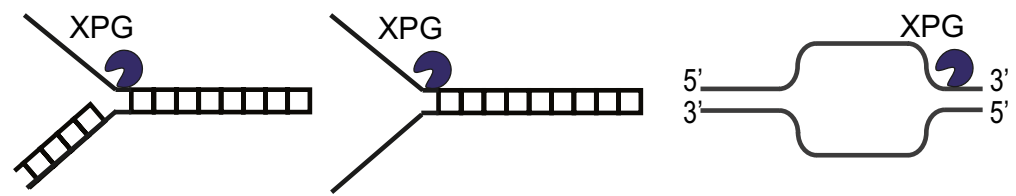

5' flap structure

Splayed arm

Bubble DNA

B

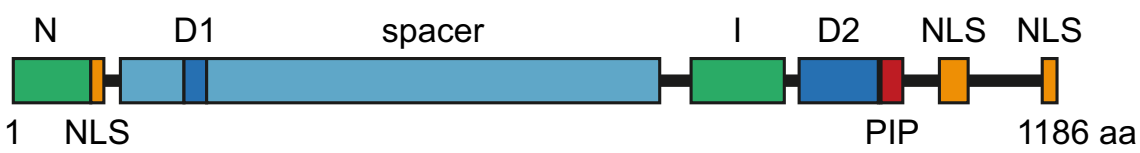

C

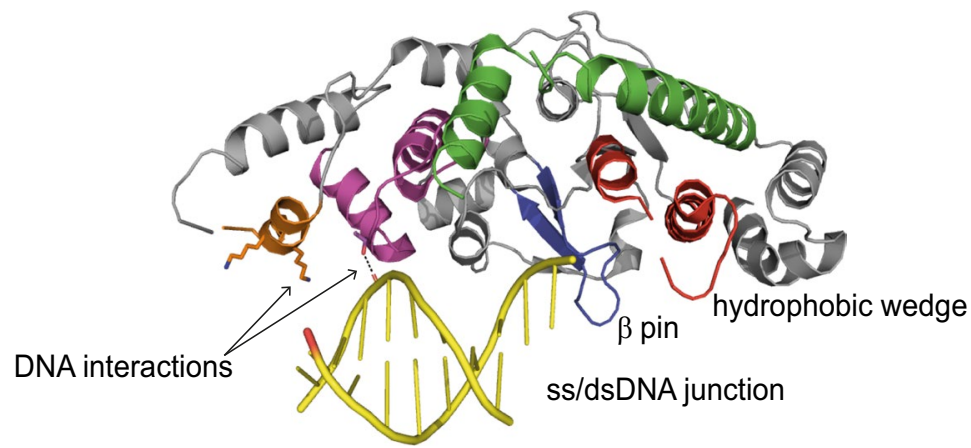

Fig. 2 XPG structure and DNA substrate binding. A DNA substrates of XPG. XPG binds to and incises $5^{\prime}$ flap structures, 5' singlestranded tails of splayed arms, and the $3^{\prime}$ junction of DNA bubbles. B XPG schematic structure. XPG contains two nuclease domains N and I, separated by a unique spacer region, a PCNA-interacting Protein (PIP) box and three Nuclear Localization Signal (NLS) regions. The D1 and D2 boxes are highly conserved among eukaryotes. C

DNA lesion after TFIIH has unwound the DNA, this interaction is probably important for stable association and/or positioning of XPG [34].

XPG is a 1186-amino acid protein consisting of two conserved nuclease domains, i.e., the $\mathrm{N}$ and I region, which it shares with other nucleases but which are separated by a spacer region that is unique to XPG [45, 54] (Fig. 2b). In addition, two regions were identified that are strongly conserved among higher eukaryotes, referred to as the D1 and D2 boxes [55], of which the first overlaps with a predicted ubiquitin binding motif (UBM) [56]. Also, XPG contains three nuclear localization sequences and a PIP-box motif for interaction with PCNA [57, 58]. Multiple subunits of TFIIH, including XPB, XPD, p52 and in particular also p62, via its Pleckstrin homology $(\mathrm{PH})$ domain, were found to interact with multiple sites within XPG $[32,59,60]$. Structural and genetic studies of the yeast XPG homolog Rad2 identified two acidic segments within the Rad2 spacer region $\left(\operatorname{Rad} 2_{642-690}\right.$ and $\left.\operatorname{Rad} 2_{359-383}\right)$ that have high affinity for the PH domain of Tfb1, the yeast homolog of p62, and functionally stimulate NER $[61,62]$. The PH motifs of yeast $\mathrm{Tfb} 1$ and human p62 are very similar [63], suggesting
XPG interactions with DNA. Crystal structure of the catalytic core of XPG in complex with a splayed-arm DNA substrate. XPG interacts with dsDNA via a helix-2-turn-helix $(\mathrm{H} 2 \mathrm{TH})$ module (shown in purple) and an adjacent $\alpha$-helix (shown in orange). Furthermore, a hydrophobic wedge and $\beta$-pin interact with the ss/dsDNA junction. Image depicts structure PDB 6TUW (complex 1) from [76] and was generated using PyMol

functional conservation even though the sequence of the spacer region in XPG is not strongly conserved. Indeed, chemical crosslinking of purified XPG, in complex with TFIIH, XPA and a DNA substrate, suggests a direct interaction of the spacer region with p62 [32]. Moreover, the disordered C-terminus of XPG appears to mostly interact with XPB and p52, while the N-terminal part of the spacer region mostly interacts with XPD. Interestingly, deletions specifically of the $\mathrm{N}$-terminal part of the spacer region were found to disrupt interactions with TFIIH and impair XPG endonuclease activity, causing an increase in UV sensitivity in cells [64, 65].

In GG-NER, upon damage detection, XPC recruits TFIIH to sites of damage via interactions with its XPB and p62 subunits, as indicated by binding experiments with purified proteins $[27,66]$. Because XPB and p62 also appear to be involved in XPG recruitment $[59,60]$ and because in in vitro reconstituted NER assays XPG binding to DNA damage coincides with XPC dissociation [67, 68], it is thought that XPG exchanges with XPC upon recruitment to DNA damage. In fact, XPC and its yeast ortholog Rad4 were shown to contain similar acidic binding motifs as XPG/Rad2 with 
which they interact with the PH domain of p62/Tfb1 and compete for binding with XPG/Rad2 $[69,70]$. The idea that XPC and XPG exchange is further supported by live cell imaging studies showing that inefficient XPC dissociation, due to inhibition of its RNF111-mediated ubiquitylation, impairs the stable integration of XPG into active NER preincision complexes [71]. It is, however, currently unclear how this exchange of XPC and XPG binding to TFIIH can be reconciled with the idea that XPG is already bound to TFIIH in the absence of DNA damage [50, 51]. Possibly, this involves structural changes and/or dimerization of XPG, as has been recently suggested to occur [72], which would allow XPG to bind in an alternate fashion and more tightly to TFIIH upon DNA damage recruitment and would position XPG for DNA incision.

It is often assumed that XPG is similarly recruited by its interaction with TFIIH in TC-NER, but this has not been formally shown. After initiation of TC-NER by binding of CSB to lesion-stalled Pol II, CSA is recruited, which, together with ELOF1, promotes recruitment of the UVSSA protein $[15,16,21,28]$. Subsequently, TFIIH is recruited by interaction with UVSSA, which has a similar acidic motif as XPC and XPG and binds to TFIIH through the PH domain of p62 $[26,28]$. Therefore, it is conceivable that, in TC-NER, XPG exchanges binding to TFIIH with UVSSA as it does with XPC in GG-NER. It is, however, unclear whether TFIIH has a similar role in opening DNA in TC-NER as in GG-NER, to generate the proper substrate for XPG incision, as within the transcription bubble of lesion-stalled Pol II the DNA is already unwound [15]. Therefore, it is possible that XPG recruitment and its stable association to TC-NER complexes involve additional or different mechanisms. In support of this, it was found that in vitro XPG can interact directly with stalled Pol II and CSB in a transcription-sized DNA bubble $[59,73]$. Also, TFIIH was found to interact with the RPB6 subunit of Pol II directly via the PH domain of p62 [74], implying that recruitment and/or stable association of XPG with TC-NER complexes additionally involves direct interactions of XPG and TFIIH with stalled Pol II. Interestingly, incision of the transcription bubble by XPG was inhibited by stalled Pol II in the absence of TFIIH [73], which suggests that in TC-NER TFIIH activity may be required to remodel lesion-bound Pol II to permit DNA incision.

\section{XPG structure, DNA-binding and dimerization}

Several structure-based studies have provided important insights into XPG's DNA binding, substrate specificity and incision. DNA-binding and footprinting assays with purified XPG showed that XPG mainly binds to the dsDNA part of a splayed-arm structure and cuts 1 nt into the DNA duplex, preferably if a 5' ssDNA overhang is present [49]. Crystallization of the catalytic core domain of Rad2 and XPG in complex with a DNA substrate furthermore revealed that Rad2/XPG interacts via several structural motifs with dsDNA and the ssDNA/dsDNA junction that mimic the NER DNA bubble structure $[75,76]$. The key interactions with DNA are mediated by a helix-2-turn-helix (H2TH) module of XPG with a flanking $\alpha$-helix that binds both strands of the dsDNA (Fig. 2C). The other key contact is with the ss/dsDNA junction and is mediated by a 'hydrophobic wedge' and $\beta$-pin that forms a protrusion. Interestingly, the human XPG structure shows the existence of a helical arch pore suggesting the possibility of threading of the $5^{\prime}$ DNA flap before incision [76], but this needs further investigation. Although not evident from these crystal structures, it is interesting to note that there are indications that XPG acts as a dimer. Whether XPG acts in NER as mono- or multimer has been for long a topic of debate. XPG appears to diffuse freely through the nucleus without being part of a larger complex [35] and when purified exists as monomer in high salt conditions, but co-immunoprecipitation experiments of XPG with itself from insect or human cells suggest that XPG can form dimers [72, 77]. Also, purification of XPG through size-exclusion chromatography shows a peak of which the molecular mass is in accordance with a dimer. Mutation of residues in a putative dimer interface of XPG led to protein destabilization and reduced incision activity of a bubble substrate [72]. Intriguingly, dimerization could imply that XPG interacts with dsDNA on both sides of a NER DNA bubble structure, which could be functionally relevant to XPF-mediated incision, as discussed below.

\section{Non-catalytic functions and dissociation of XPG from DNA damage}

XPG does not only have a catalytic but also a structural role in NER. XPG stably associates with TFIIH and stabilizes the complex [51] and, in vitro, stimulates XPD helicase activity and DNA opening by TFIIH [32]. Cryo-EM and chemical crosslinking studies of TFIIH, XPA and XPG bound to a DNA substrate suggest that the XPB translocase and XPD helicase activities are inhibited by interaction of XPD with the CAK (cyclin-dependent kinase activating kinase) TFIIH subcomplex formed by MNAT1, CDK7, and Cyclin $\mathrm{H}$. The CAK subcomplex mediates important transcription functions of TFIIH, such as, e.g., phosphorylation of Pol II, but is dispensable for NER [30]. Binding of XPA stabilizes a TFIIH conformation that cannot bind CAK, in line with the observation that XPA stimulates dissociation of this subcomplex from TFIIH during NER [33], which would, thus, relieve this inhibition. Interestingly, the $\mathrm{N}$-terminus of XPG also interacts with XPD at its binding site for the 
CAK subcomplex, suggesting that competition with CAK for binding to XPD is how XPG can stimulate XPD helicase activity.

Upon recruitment of TFIIH, XPA, RPA and XPG to DNA damage, damage removal is initiated by DNA incision at the 5' site of the lesion by ERCC1-XPF, such that repair synthesis can also be started. This depends on the structural presence of XPG but does not require its catalytic activity $[36,78]$. Only after ERCC $1-X P F$ incision, XPG cuts at the $3^{\prime}$ site of the lesion. It is currently unclear how the mere presence of XPG at the NER bubble substrate facilitates ERCC1-XPF-mediated incision and, vice versa, how its 5' incision subsequently provokes 3' incision by XPG. It has been suggested that XPG dimerization might allow XPG to bind both $3^{\prime}$ as well as $5^{\prime}$ to the NER bubble substrate, close to XPF, thus facilitating its incision [72]. Furthermore, XPG activation and incision has been hypothesized to be induced by a conformational change in the NER incision complex or by a structural rearrangement in XPG itself, such as a posttranslational modification, due to either ERCC1-XPFmediated 5' incision or due to initiation of DNA repair synthesis following this $5^{\prime}$ incision $[6,36,54]$.

Following dual incision, it is unclear what exactly happens to XPG. Some NER proteins that have performed their activity are actively unloaded, involving posttranslational modifications and the activity of other proteins, such as DDB2 by the segregase VCP/p97 [14, 79] and XPC by the E3 ubiquitin ligase RNF111 [71]. The dissociation of other NER proteins appears to coincide with the release of the excised damaged DNA oligomer. Excision assays in cellfree extracts and cells showed that NER-excised DNA fragments are in tight complex with TFIIH [80], but also with XPG, possibly because of its strong association to TFIIH [81]. This suggests that XPG might dissociate along with the excision product upon incision. However, it has been suggested that, besides incising DNA, XPG is involved in DNA re-synthesis by helping to recruit DNA synthesis factors, in particular PCNA, indicating that XPG initially remains bound after incision. In vitro reconstitution of dual incision of a cisplatin-DNA adduct suggested that excision coincides with the dissociation of several factors, including TFIIH and XPF, but that XPG and RPA remain bound to DNA to participate in DNA re-synthesis, likely by helping recruit RFC and PCNA [67, 82]. Recruitment of PCNA to DNA damage indeed depends on XPG [83], but so does the 5 ' incision by XPF [36]. In the presence of nuclease-inactive XPG, ERCC1-XPF can incise DNA and post-incision NER factors, including PCNA, are recruited, pointing to the possibility that DNA repair synthesis can be initiated before $3^{\prime}$ incision by XPG takes place [36]. XPG has been implicated in recruiting PCNA through a direct interaction with a PIPbox motif in its C-terminus [57]. PCNA furthermore interacts with XPA [84], which might regulate its recruitment, and RFC, which is needed to properly load the PCNA clamp around DNA [85]. Thus, it was postulated that XPG recruits PCNA before incising the damage at the $3^{\prime}$ site after which PCNA is correctly loaded by RFC after $5^{\prime}$ incision and XPF dissociation [86]. Since it was found that XPG is bound to excised DNA fragments [81], this suggests that even though XPG may initially, before or during 5' DNA incision, help to recruit PCNA, it rapidly dissociates together with the excised DNA fragment once the dual incision takes place, handing over PCNA to RFC and possibly XPA. Alternatively, it was proposed that upon incision and recruitment of PCNA, XPG is ubiquitylated by the $\mathrm{E} 3$ ubiquitin ligase complex CRL4 ${ }^{\mathrm{Cd} 2}$ and subsequently degraded, to make room for subsequent DNA synthesis factors [87]. However, even though ubiquitylation of XPG after UV has been reported by others as well $[88,89]$, its precise function and whether this indeed promotes XPG removal, requires further confirmation.

\section{XPG functions beyond NER}

\section{Transcription and base excision repair}

Besides being involved in NER, XPG has been implicated in other DNA transacting and maintenance mechanisms (Fig. 3). Together with other NER proteins, XPG has been implicated in regulating transcription, both by stabilizing TFIIH [51] as well as by promoting demethylation and, through the generation of DNA breaks, recruitment of the chromatin organizer CTCF to gene promoters [90, 91]. Also in yeast, Rad2/XPG was implicated in regulating transcription through an interaction with Pol II and Mediator [92, 93]. Furthermore, XPG is implicated in the removal of oxidative DNA damage by base excision repair (BER). This pathway resembles NER in that it mediates excision of a damaged base, but both the detection of oxidative base lesions, by various glycosylases, as well as the removal of the lesion and gap filling are performed by a different set of proteins. Still, emerging evidence suggests that substantial interplay between the NER and BER machineries exists [94] and multiple NER proteins have been implicated in stimulating BER activity, even though the precise involved mechanisms are not yet understood [95-99]. Cells deficient in several NER proteins, including XPG, show reduced repair of and/or are hypersensitive to oxidative DNA damage [100], suggesting a function in the removal of oxidative DNA lesions. Interestingly, in an in vitro reconstituted BER system, XPG was found to stimulate the DNA-binding activity of the DNA glycosylase NTH1, which detects and removes oxidized bases, independently of its endonuclease activity [101, 102]. Interaction between XPG and NTH1 was furthermore confirmed in cells [103]. These data suggest a possible role for XPG in the removal of oxidative lesions that is independent 


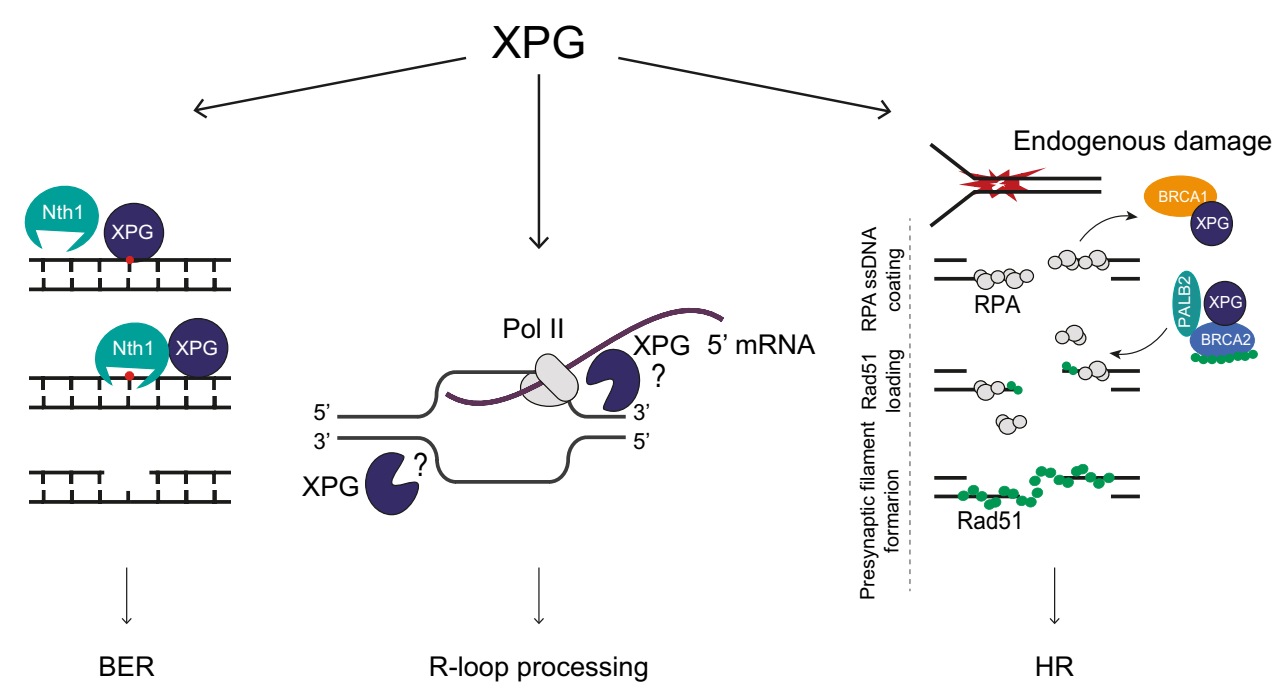

Fig. 3 XPG functions in genome maintenance pathways other than NER. A Repair of oxidative damage. Initial binding of XPG to an oxidized base stimulates Nth1 DNA-binding activity, followed by removal of the oxidized base and repair by BER. B R-loop processing. R-loops arise when during Pol II transcription the nascent mRNA hybridizes with one of the DNA strands. One of the 3 ' prime junctions of the resulting bubble structure is recognized and processed by XPG endonuclease activity. C Homologous Recombination. HR

from NER, but further studies, especially cellular or in vivo experiments, are needed to support this notion.

\section{Resolving R-loops}

One of the major activities of XPG besides NER appears to be in resolving R-loops. These are three-stranded RNA-DNA hybrid-containing structures that originate during transcription when the nascent RNA molecule from the transcription machinery hybridizes with the DNA template strand. Physiological R-loops are commonly found in many organisms and are implicated in transcription regulation. However, pathological R-loops may arise in an unscheduled fashion, for instance due to transcription blockage or defects in RNA processing, and by interference of DNA replication with transcription [104]. Cells have developed multiple specialized mechanisms to cope with these R-loops, including RNA degradation by ribonucleases and RNA-DNA hybrid unwinding by helicases. When these mechanisms fail, RNA-DNA hybrid structures can lead to DNA damage and genomic instability, although they are thought to play a faciliatory role in DDR as well $[105,106]$. Interestingly, since R-loops form bubble structures that resemble substrates for ERCC1-XPF and XPG, both NER endonucleases are considered as candidates to process R-loops. Indeed, ERCC1-XPF and XPG can cleave R-loops in vitro [107]. Furthermore, it was observed in cells that the depletion of the R-loop helicase AQR resulted in more R-loop of DSBs generated by endogenous DNA damage is initiated by DNA end resection followed by RPA coating of the resulting ssDNA. XPG interacts with and facilitates the loading of the BRCA2-PALB2RAD51 complex to DSB sites. RAD51 replaces RPA and promotes the presynaptic filament to initiate HR. Of note, closed XPG circles represent putative non-catalytic activity and open XPG circles represent catalytic activity of XPG

formation and fewer DNA breaks if XPF or XPG are deficient [108]. Because of these and similar findings with other TC-NER factors, it was proposed that TC-NER processes R-loops associated with paused transcription into doublestrand breaks (DSBs) [108, 109]. Interestingly, in line with this idea, it was found that the HLTV-1 viral oncoprotein Tax promotes cellular senescence by inducing an increase in R-loops that results in excessive DSB formation by XPF and XPG [110]. Therefore, HTLV-1-induced adult T-cell leukemias avoid senescence by selection for cells that have lost the activity of XPG or other TC-NER proteins.

XPG was also found to be recruited to R-loops generated at DSBs in transcriptionally active regions, in a Rad52dependent manner, to help resolve R-loops and stimulate repair by transcription-associated homologous recombination [111]. Additional evidence that XPG processes R-loops comes from the observations that XPF and XPG form a complex together with the splicing factor XAB2, which is independent of NER, that is targeted to R-loops [112]; that XPG co-localizes with R-loops [113]; and that there is reduced DSB formation upon XPG depletion in cells with increased R-loops, due to camptothecin-induced transcription blockage [114] or due to replication-fork stalling in Werner protein deficient cells [115]. Together, these results strongly suggest that XPG is an important factor for cells to deal with $\mathrm{R}$-loops, but it remains to be investigated to which types of R-loops and processing mechanisms XPG is important and with which other R-loop processing factors it interplays. 
Contradicting results still exist and should be resolved before a clear understanding of XPG function in regulating R-loop metabolism is obtained. For instance, both XPF and XPG, as part of the whole TC-NER machinery, were implicated in resolving R-loops when other mechanisms that prevent their excessive formation are inhibited [108]. On the contrary, only XPG, but not XPF, was found to be recruited to and help resolve R-loops at DSBs in transcriptional active regions [111]. This may suggest that XPG can mediate R-loop processing independently from (TC-)NER, but it is unclear how XPG is recruited and, especially, positioned and activated to cleave R-loops. Given the tight regulation of XPG (and XPF) function in NER, by multiple protein-protein interactions, it seems reasonable to assume that similar mechanisms exist to prevent unwanted XPG-mediated incisions during R-loop metabolism. How this is accomplished is currently unknown and should be further investigated.

\section{Homologous recombination and replication stress}

Besides processing R-loops at stalled replication forks [115], XPG may also function non-enzymatically to counteract replication stress. Purified XPG binds fork-like structures [49, 72] and in cells XPG was shown to interact and colocalize at stalled forks with the WRN helicase, which is thought to serve as fork-protection factor during replication stress [116]. Interestingly, independently of its catalytic activity, XPG was able to stimulate both the helicase and annealing activity of WRN in vitro. Furthermore, XPG was found to have a non-catalytic role in recovery from replication stress by promoting homologous recombination [117]. XPG interacts with multiple homologous recombination proteins, including BRCA2, PALB2 and RAD51, and promotes their loading at DSB sites. In addition, XPG interacts with BRCA1 and promotes its dissociation from chromatin [117]. In spite of these intriguing findings, much of the proposed functions of XPG in replication stress and homologous recombination still await further confirmation and should be investigated in more detail to precisely understand the structural role of XPG in maintaining genome stability of replicating cells. Also, in transcriptionally active chromatin, XPG recruitment to R-loops at DSB sites may indicate that XPG can have a double role in promoting HR. First, XPG may help resolve R-loops by its endonucleolytic activity, after which it may further promote repair by its association with HR factors. It would therefore be interesting to investigate the connection between these enzymatic and non-enzymatic functions in HR.

\section{XPG and human disease}

The multiple tasks that XPG performs both enzymatically and structurally in genome maintenance, replication and transcription imply that it must be an essential and critical factor for cellular homeostasis and organismal development and growth. Indeed, hereditary mutations in XPG are associated with several rare human diseases characterized by a perplexing broad spectrum of symptoms including cancer predisposition, progressive neurodegeneration and developmental failure (Tables 1, 2, 3; Supplementary Table 1). Mild XPG mutations cause xeroderma pigmentosum (XP), which is characterized by photosensitivity, abnormal skin pigmentation, increased risk of cancer and sometimes, but not always, neurological diseases (Table 1). Many of these patients express XPG mutant proteins carrying a missense or frame-shift mutation near the catalytic core that disrupts or reduces XPG DNA-binding and/or nuclease activity and, thus, NER efficiency $[76,77]$. XP symptoms are therefore thought to be mainly caused by reduced or defective GGNER, in which the degree of the repair defect will correlate with the severity of symptoms. More severe mutations, which often truncate the XPG protein or, in case of missense mutations, are thought to disrupt the entire protein function, stability and interactions [72], cause additional Cockayne syndrome features, called xeroderma pigmentosum-Cockayne syndrome (XPCS) complex (Table 2), also referred to as cerebro-oculo-facio-skeletal (COFS) syndrome when very severe (Table 3) [118]. XPCS complex patients are characterized by mental retardation, bird-like faces, dwarfism and developmental delay, progeria and severe, progressive neurological abnormalities.

Like humans, model organisms such as $S$. cerevisiae and C. elegans with XPG deficiency show mild to severe growth and developmental defects $[119,120]$. In addition, several XPG mouse models have been generated that recapitulate disease phenotypes. Strikingly, mice with point mutations inactivating XPG endonuclease activity or lacking the last 183 amino acids were UV sensitive, but otherwise normal, whereas mice lacking XPG completely or its last 360 amino acids (including half of the I domain) showed progressive growth retardation upon birth and died prematurely [121-123]. In line with this, conditional XPG knockout mouse models also showed shortened lifespan and many growth deficiencies including progressive progeroid features and neurodegeneration, whose severity strikingly depends on the genetic background of the mice [124].

It is still debated why truncations and certain mutations in XPG cause more severe phenotypes and in humans lead to progeroid CS features in addition to XP. Typically, CS is associated with hereditary defects in TC-NER proteins such as CSA and CSB, suggesting that XPG-XPCS mutations 


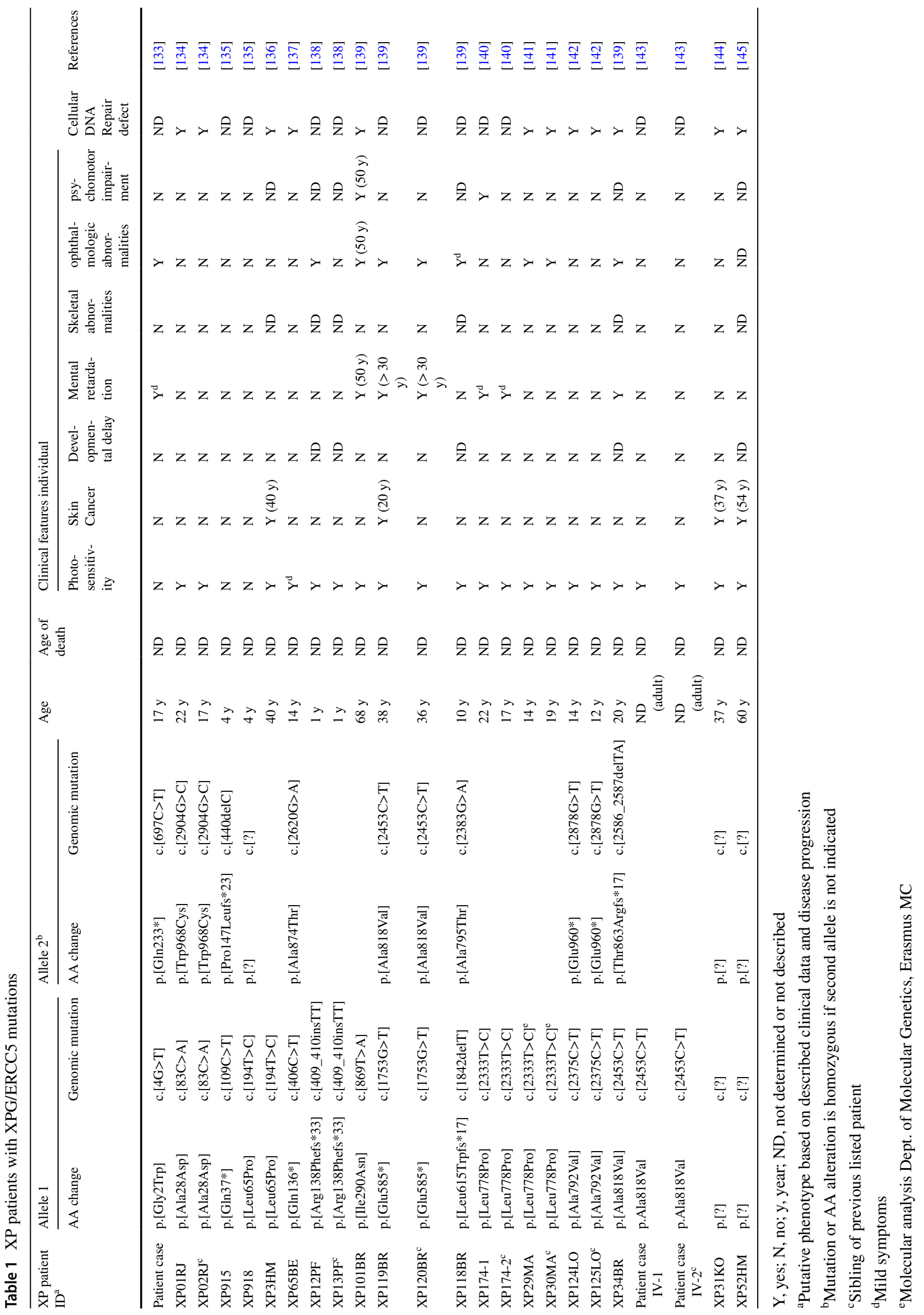




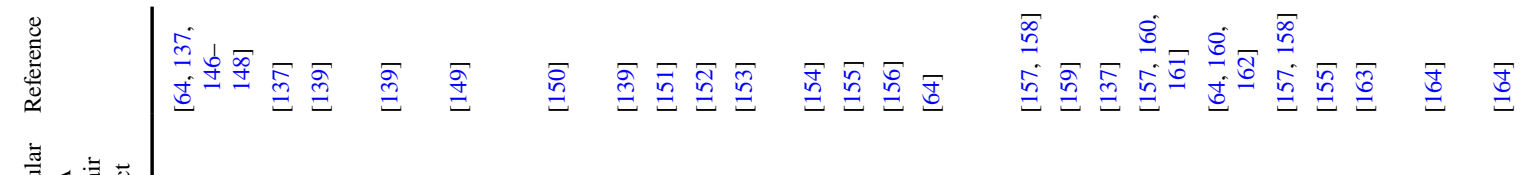

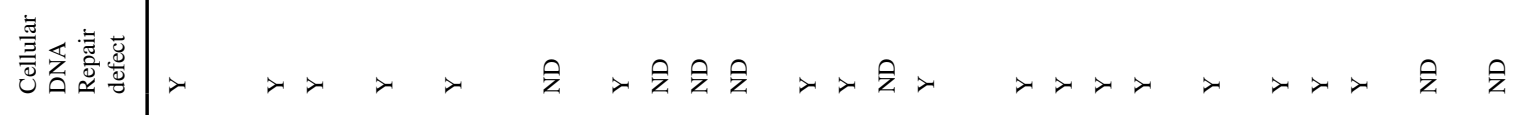

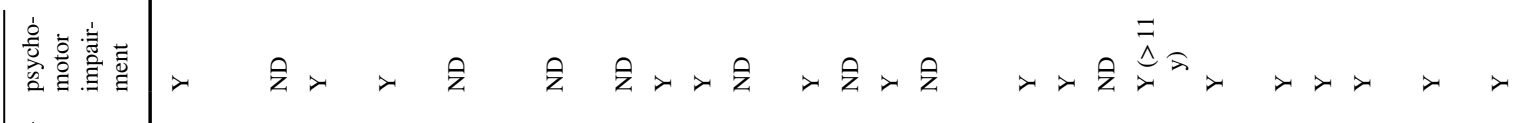

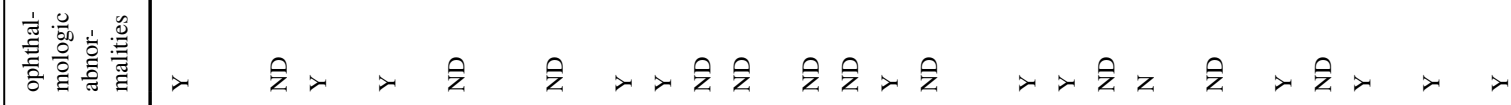

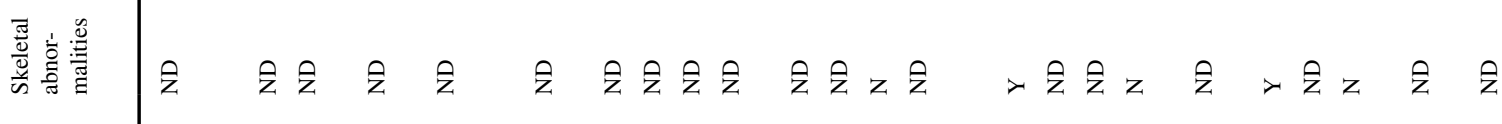

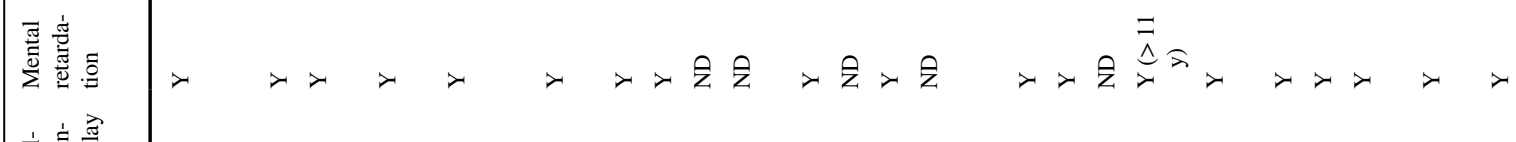

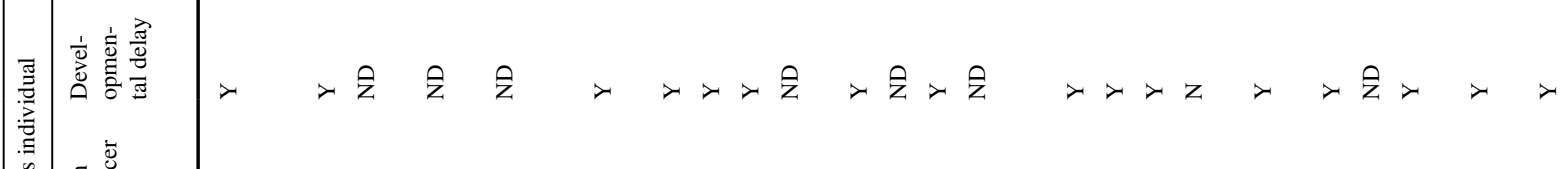

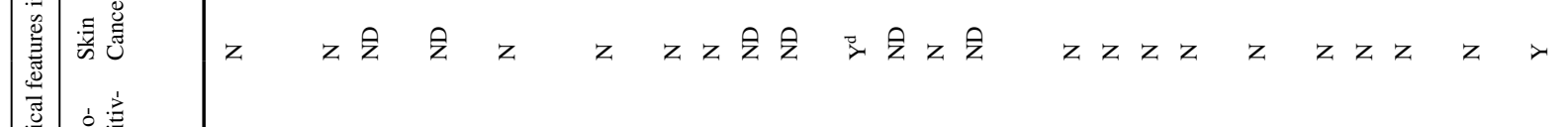

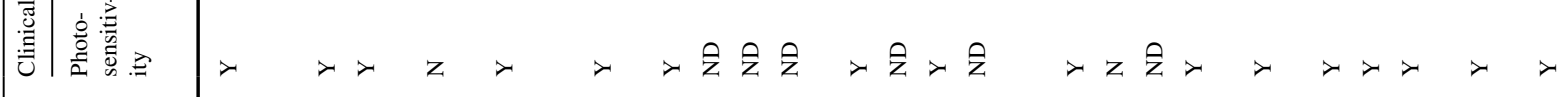

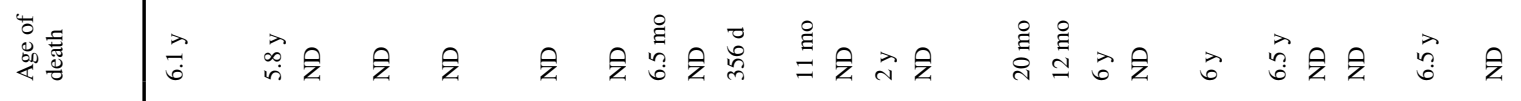

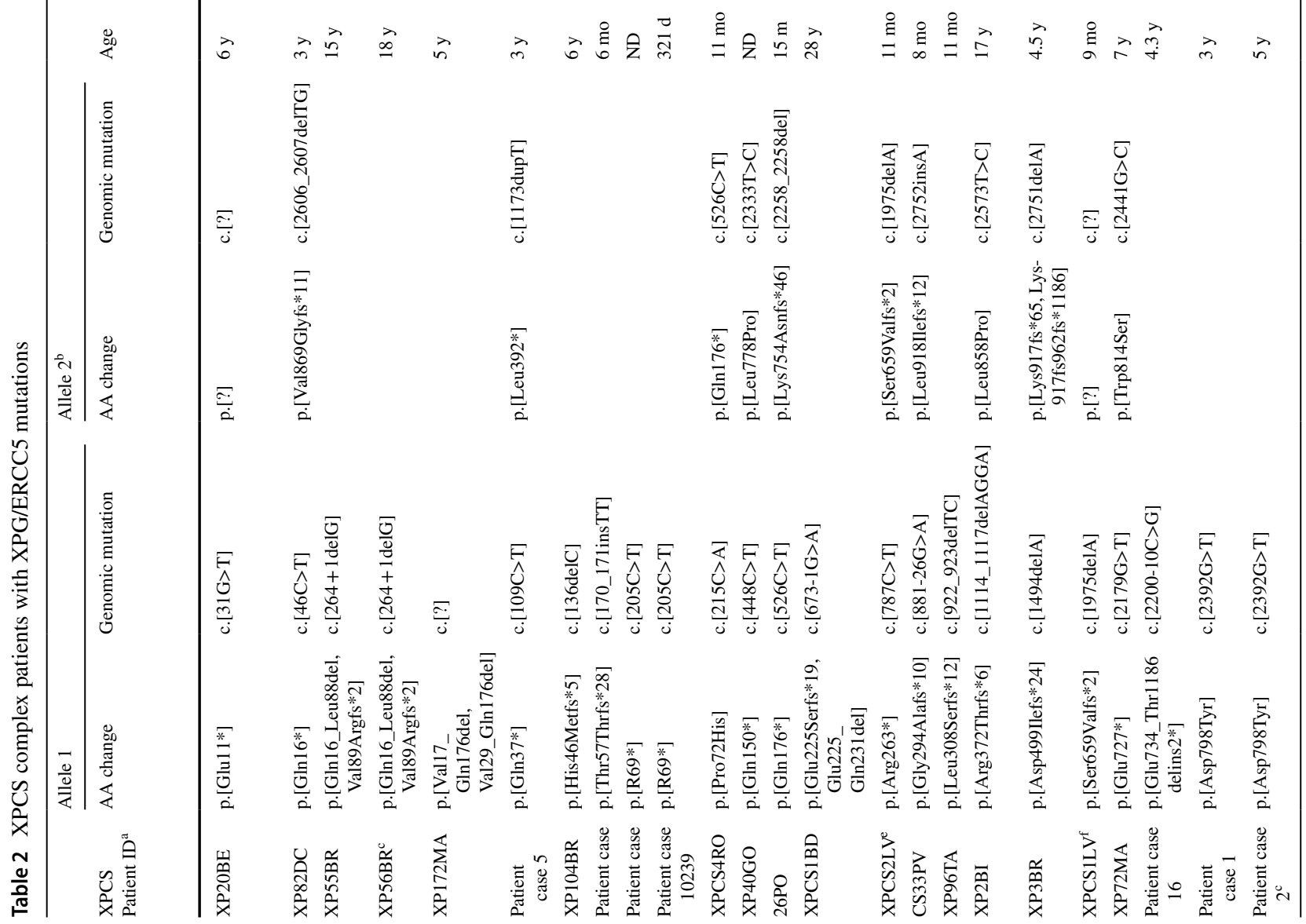




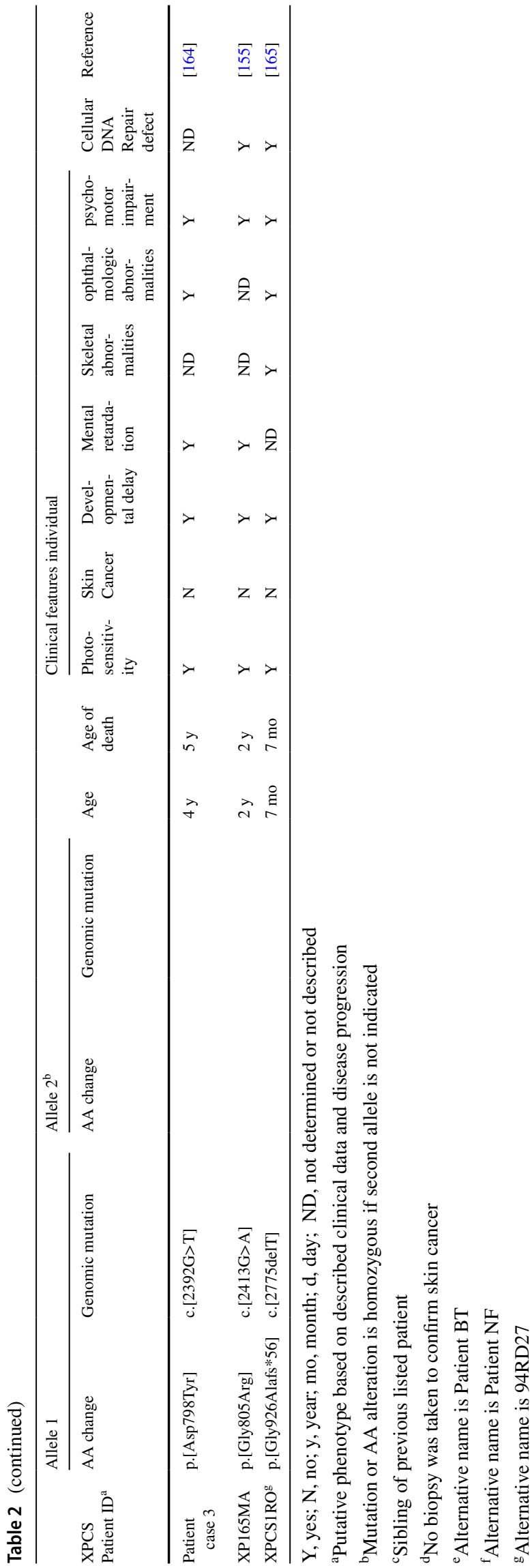

may reduce TC-NER besides GG-NER. However, mutations in the TC-NER protein UVSSA and some mutations in CSA and CSB do not cause CS, but the rather mild photosensitive disorder UV sensitive syndrome, indicating that mere TC-NER deficiency is not the underlying cause for the additional severe symptoms. Possibly, a function of XPG outside NER plays a role in disease development. Human patients and mouse models expressing intact but nucleaseinactive XPG do not typically show severe CS-like features, suggesting that it is not the loss of enzymatic activity but the loss of non-enzymatic and/or structural functions of XPG that is linked to a more severe phenotype. Because of this, multiple hypotheses have been put forward to explain the pathogenesis of CS involving non-NER functions for XPG and other NER proteins. For instance, because XPG strongly interacts with and stabilizes TFIIH, a feature that is disrupted by a CS-causative mutation, it was suggested that gene expression problems may give rise to some of the more severe CS symptoms [51]. Furthermore, possibly truncating XPG mutations may specifically impair non-catalytic roles of XPG such as in oxidative DNA damage repair [101, 102] or in homologous recombination and/or replication fork protection [116, 117], giving rise to more severe developmental defects as observed in CS. Oxidative DNA damage repair may be particularly relevant to neurological CS features because oxidative lesions occur endogenously in cells like neurons that are not exposed to the environment and because some types of oxidative lesions are repaired by TC-NER [125]. Notably, like XPG, the TC-NER factors CSA and CSB have also been implicated in repair of oxidative damage via BER. $C S-A$ and $C S-B$ patient cells are hypersensitive to oxidative DNA damage and show accumulation of oxidative lesions [94, 126-128]. Also, CSB has been reported to interact with multiple BER factors, such as PARP1 [129] and APE1 [130] and to promote recruitment of XRCC1 to sites of oxidative DNA damage [95]. It has been suggested that transcription blockage by accumulation of oxidative damage might trigger neuronal cell death or senescence [125, 131]. Therefore, it is possible that specific CSA, CSB or XPG mutations result in deficient removal of oxidative lesions, leading to blocking of transcription and, consequently, triggering of CS symptoms. Moreover, also the emerging role of XPG in R-loop processing may be relevant to some aspects of the CS pathology, as in the absence of XPG R-loop levels will increase that may cause genome instability $[104,108$, 111]. This may be even exacerbated due to the absence of functional TC-NER, as transcription-blocking DNA lesions lead to spliceosome displacement which causes the mRNA to hybridize with template ssDNA and form R-loops [106]. Moreover, these R-loops were shown to trigger noncanonical ATM activation leading to alternative spliced transcripts and differences in gene expression that might adversely affect cell function. Despite these possibilities, we favor an 


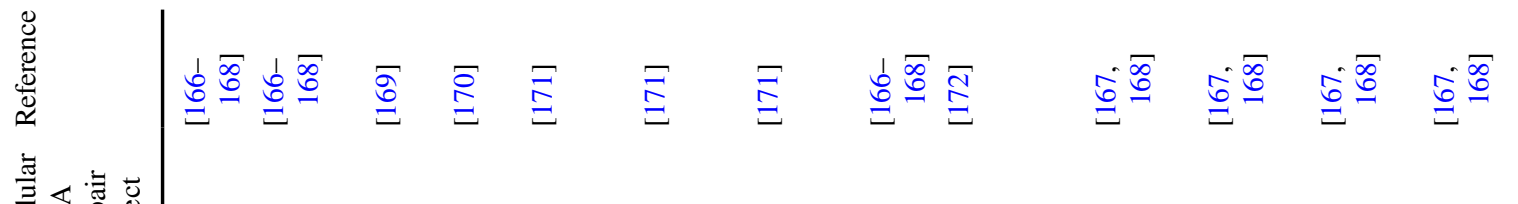

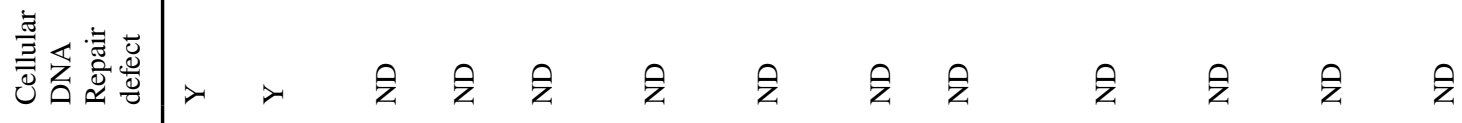

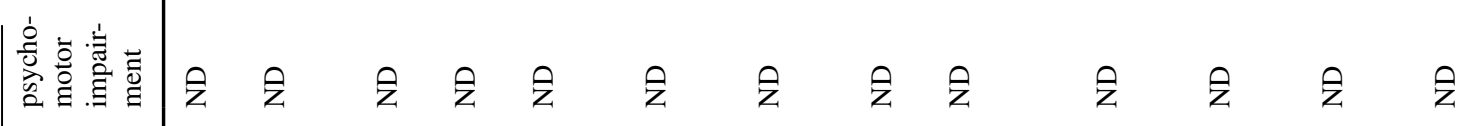

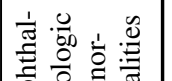

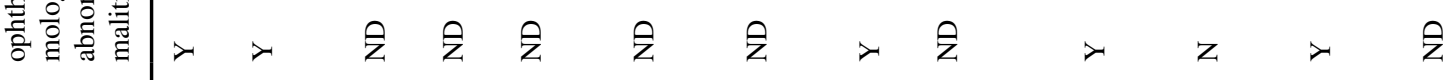
焉 苞密 会会会

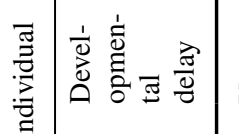

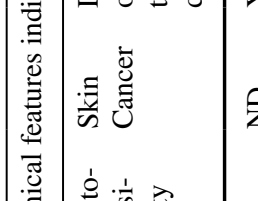

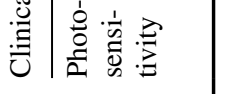

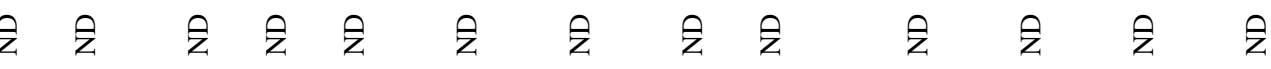
哆

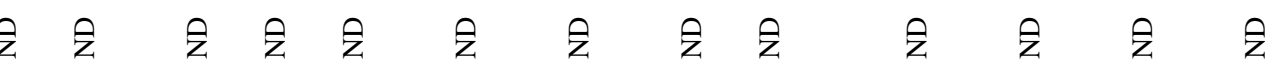

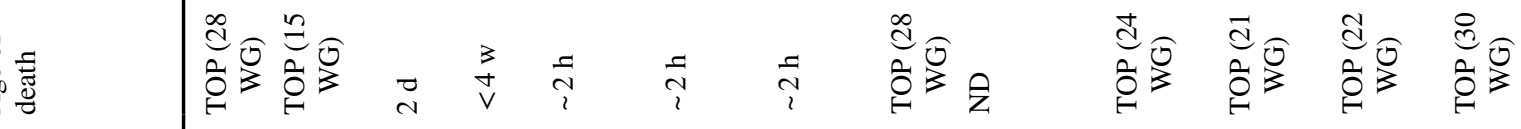

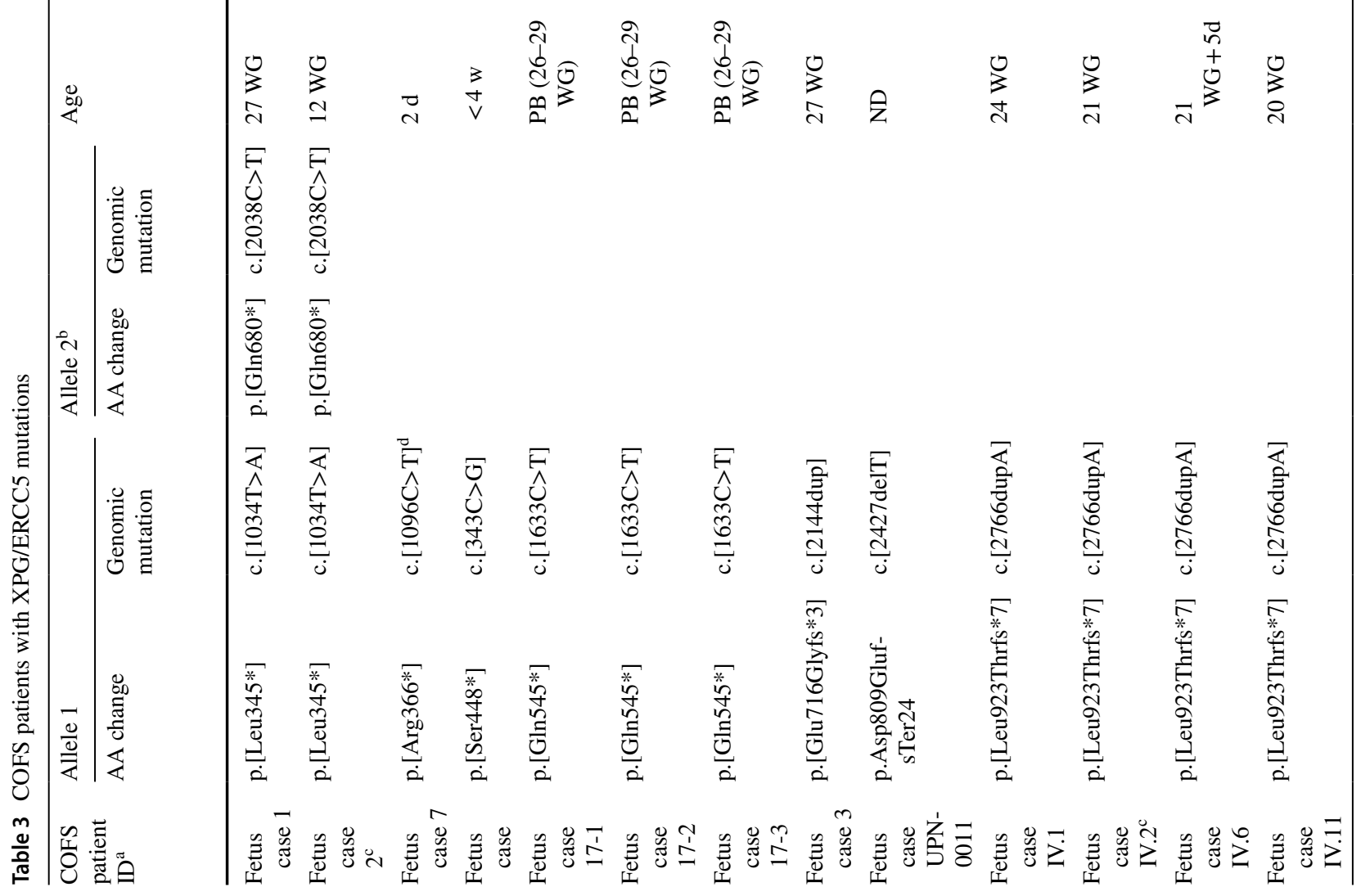




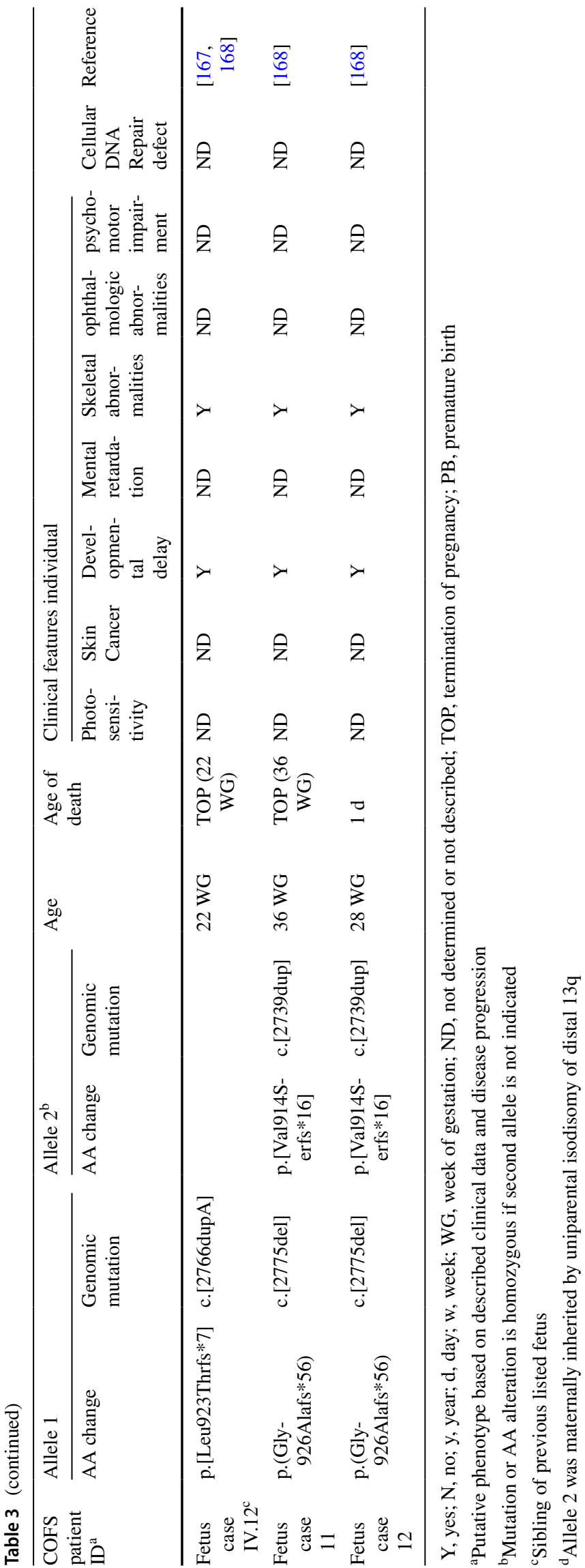

explanation that takes into account the fact that only mutations in TC-NER genes, albeit not all, cause CS features, which strongly points to a pathogenic connection with the TC-NER process itself. We noticed previously that in XPF- and XPG-deficient XPCS complex cells the core NER machinery is continuously targeted to DNA damage due to the absence of repair [132]. Therefore, we proposed that additional CS features are caused by the inability to remove stalled NER intermediates, either involving Pol II or TFIIH, which would prevent repair of the lesion by other means and could interfere with transcription and replication [15]. More research is needed to prove the value of this and other hypotheses, focusing on the pathogenic impact of different disease-causing mutations in XPG on the exact molecular buildup of the TC-NER machinery and on TC-NER efficiency with regard to different types of endogenously occurring DNA damage.

In summary, although XPG was originally identified as a major endonuclease in NER, it has now become clear that the protein has important functions outside NER as well. Future research should be aimed at better understanding how the activity of XPG in these different pathways is regulated. In particular, it is not yet exactly clear whether XPG is recruited to the NER machinery separately or as part of TFIIH, whether it forms a dimer and when and how it dissociates after incision. Also, how its recruitment to and stable association with transcription sites, other types of DNA damage and repair pathways and R-loops are regulated is not known. Finally, a systematic comparison of XPG disease mutations and their impact on XPG functions and associated phenotypes in isogenic cellular or animal models may be helpful to elucidate how exactly its deficiency leads to certain disease symptoms.

Supplementary Information The online version contains supplementary material available at https://doi.org/10.1007/s00018-022-04194-5.

Acknowledgements We thank Melanie van der Woude for help with PyMol.

Author contributions AMV, AT and CRS generated figures and tables. AT and WV edited the manuscript. AMV, CRS and HL wrote the manuscript.

Funding This work was supported the European Research Council (advanced Grant 340988-ERC-ID), Erasmus MC (HDMA Grant), the Dutch Cancer Society (KWF Grant 10506) and the gravitation program CancerGenomiCs.nl from the Netherlands Organization for Scientific Research. Oncode Institute is partly financed by the Dutch Cancer Society.

Availability of data and materials Not applicable. 


\section{Declarations}

Conflict of interest The authors declare that they have no conflict of interest.

Ethics approval and consent to participate Not applicable.

Consent for publication Not applicable.

Open Access This article is licensed under a Creative Commons Attribution 4.0 International License, which permits use, sharing, adaptation, distribution and reproduction in any medium or format, as long as you give appropriate credit to the original author(s) and the source, provide a link to the Creative Commons licence, and indicate if changes were made. The images or other third party material in this article are included in the article's Creative Commons licence, unless indicated otherwise in a credit line to the material. If material is not included in the article's Creative Commons licence and your intended use is not permitted by statutory regulation or exceeds the permitted use, you will need to obtain permission directly from the copyright holder. To view a copy of this licence, visit http://creativecommons.org/licenses/by/4.0/.

\section{References}

1. Hoeijmakers JHJ (2001) Genome maintenance mechanisms for preventing cancer. Nature 411:366-374. https://doi.org/10.1038/ 35077232

2. Lindahl $T$ (1993) Instability and decay of the primary structure of DNA. Nature 362:709-715. https://doi.org/10.1038/362709a0

3. Hoeijmakers JHJ (2009) DNA Damage, Aging, and Cancer. N Engl J Med 361:1475-1485. https://doi.org/10.1056/nejmra0804 615

4. Jackson SP, Bartek J (2009) The DNA-damage response in human biology and disease. Nature 461:1071-1078

5. Min JH, Pavletich NP (2007) Recognition of DNA damage by the Rad4 nucleotide excision repair protein. Nature 449:570-575. https://doi.org/10.1038/nature06155

6. Schärer OD (2013) Nucleotide excision repair in Eukaryotes. Cold Spring Harb Perspect Biol 5:a012609. https://doi.org/10. 1101/cshperspect.a012609

7. Marteijn JA, Lans H, Vermeulen W, Hoeijmakers JHJ (2014) Understanding nucleotide excision repair and its roles in cancer and ageing. Nat Rev Mol Cell Biol 15:465-481. https://doi.org/ $10.1038 / \mathrm{nrm} 3822$

8. Mu H, Geacintov NE, Broyde S, Yeo JE, Schärer OD (2018) Molecular basis for damage recognition and verification by XPCRAD23B and TFIIH in nucleotide excision repair. DNA Repair (Amst) 71:33-42

9. Sugasawa K, Ng JMY, Masutani C, Iwai S, Van Der Spek PJ, Eker APM, Hanaoka F, Bootsma D, Hoeijmakers JHJ (1998) Xeroderma pigmentosum group $\mathrm{C}$ protein complex is the initiator of global genome nucleotide excision repair. Mol Cell 2:223-232. https://doi.org/10.1016/S1097-2765(00)80132-X

10. Moser J, Volker M, Kool H, Alekseev S, Vrieling H, Yasui A, Van Zeeland AA, Mullenders LHF (2005) The UV-damaged DNA binding protein mediates efficient targeting of the nucleotide excision repair complex to UV-induced photo lesions. DNA Repair (Amst) 4:571-582. https://doi.org/10.1016/j.dnarep.2005. 01.001

11. Sugasawa K, Okuda Y, Saijo M, Nishi R, Matsuda N, Chu G, Mori T, Iwai S, Tanaka K, Tanaka K, Hanaoka F (2005) UV-induced ubiquitylation of XPC protein mediated by
UV-DDB-ubiquitin ligase complex. Cell 121:387-400. https:// doi.org/10.1016/j.cell.2005.02.035

12. Scrima A, Koníčková R, Czyzewski BK, Kawasaki Y, Jeffrey PD, Groisman R, Nakatani Y, Iwai S, Pavletich NP, Thomä NH (2008) Structural basis of UV DNA-damage recognition by the DDB1-DDB2 complex. Cell 135:1213-1223. https://doi.org/10. 1016/j.cell.2008.10.045

13. Groisman R, Polanowska J, Kuraoka I, Sawada JI, Saijo M, Drapkin R, Kisselev AF, Tanaka K, Nakatani Y (2003) The ubiquitin ligase activity in the DDB2 and CSA complexes is differentially regulated by the COP9 signalosome in response to DNA damage. Cell 113:357-367. https://doi.org/10.1016/S00928674(03)00316-7

14. Ribeiro-Silva C, Sabatella M, Helfricht A, Marteijn JA, Theil AF, Vermeulen W, Lans H (2020) Ubiquitin and TFIIH-stimulated DDB2 dissociation drives DNA damage handover in nucleotide excision repair. Nat Commun 11:4868. https://doi.org/10.1038/ s41467-020-18705-0

15. Lans H, Hoeijmakers JHJ, Vermeulen W, Marteijn JA (2019) The DNA damage response to transcription stress. Nat Rev Mol Cell Biol 20:766-784. https://doi.org/10.1038/s41580-019-0169-4

16. Jia N, Guo C, Nakazawa Y, van den Heuvel D, Luijsterburg MS, Ogi T (2021) Dealing with transcription-blocking DNA damage: Repair mechanisms, RNA polymerase II processing and human disorders. DNA Repair (Amst) 106:103192. https://doi.org/10. 1016/j.dnarep.2021.103192

17. Xu J, Lahiri I, Wang W, Wier A, Cianfrocco MA, Chong J, Hare AA, Dervan PB, DiMaio F, Leschziner AE, Wang D (2017) Structural basis for the initiation of eukaryotic transcriptioncoupled DNA repair. Nature 551:653-657. https://doi.org/10. 1038/nature24658

18. Fischer ES, Scrima A, Böhm K, Matsumoto S, Lingaraju GM, Faty M, Yasuda T, Cavadini S, Wakasugi M, Hanaoka F, Iwai S, Gut H, Sugasawa K, Thomä NH (2011) The molecular basis of CRL4DDB2/CSA ubiquitin ligase architecture, targeting, and activation. Cell 147:1024-1039. https://doi.org/10.1016/j. cell.2011.10.035

19. Groisman R, Kuraoka I, Chevallier O, Gaye N, Magnaldo T, Tanaka K, Kisselev AF, Harel-Bellan A, Nakatani Y (2006) CSA-dependent degradation of CSB by the ubiquitin-proteasome pathway establishes a link between complementation factors of the Cockayne syndrome. Genes Dev 20:1429-1434. https://doi.org/10.1101/gad.378206

20. Nakazawa Y, Hara Y, Oka Y, Komine O, van den Heuvel D, Guo C, Daigaku Y, Isono M, He Y, Shimada M, Kato K, Jia N, Hashimoto S, Kotani Y, Miyoshi Y, Tanaka M, Sobue A, Mitsutake N, Suganami T, Masuda A, Ohno K, Nakada S, Mashimo T, Yamanaka K, Luijsterburg MS, Ogi T (2020) Ubiquitination of DNA damage-stalled RNAPII promotes transcription-coupled repair. Cell 180:1228-1244.e24. https:// doi.org/10.1016/j.cell.2020.02.010

21. Geijer ME, Zhou D, Selvam K, Steurer B, Mukherjee C, Evers B, Cugusi S, van Toorn M, van der Woude M, Janssens RC, Kok YP, Gong W, Raams A, Lo CSY, Lebbink JHG, Geverts B, Plummer DA, Bezstarosti K, Theil AF, Mitter R, Houtsmuller AB, Vermeulen W, Demmers JAA, Li S, van Vugt MATM, Lans H, Bernards R, Svejstrup JQ, Ray Chaudhuri A, Wyrick JJ, Marteijn JA (2021) Elongation factor ELOF1 drives transcription-coupled repair and prevents genome instability. Nat Cell Biol 23:608-619. https://doi.org/10.1038/ s41556-021-00692-Z

22. van der Weegen Y, de Lint K, van den Heuvel D, Nakazawa Y, Mevissen TET, van Schie JJM, San Martin Alonso M, Boer DEC, González-Prieto R, Narayanan IV, Klaassen NHM, Wondergem AP, Roohollahi K, Dorsman JC, Hara Y, Vertegaal ACO, de Lange J, Walter JC, Noordermeer SM, Ljungman M, Ogi T, 
Wolthuis RMF, Luijsterburg MS (2021) ELOF1 is a transcription-coupled DNA repair factor that directs RNA polymerase II ubiquitylation. Nat Cell Biol 23:595-607. https://doi.org/10. 1038/s41556-021-00688-9

23. Nakazawa Y, Sasaki K, Mitsutake N, Matsuse M, Shimada M, Nardo T, Takahashi Y, Ohyama K, Ito K, Mishima H, Nomura M, Kinoshita A, Ono S, Takenaka K, Masuyama R, Kudo T, Slor H, Utani A, Tateishi S, Yamashita S, Stefanini M, Lehmann AR, Yoshiura KI, Ogi T (2012) Mutations in UVSSA cause UVsensitive syndrome and impair RNA polymerase IIo processing in transcription-coupled nucleotide-excision repair. Nat Genet 44:586-592. https://doi.org/10.1038/ng.2229

24. Zhang X, Horibata K, Saijo M, Ishigami C, Ukai A, Kanno SI, Tahara H, Neilan EG, Honma M, Nohmi T, Yasui A, Tanaka K (2012) Mutations in UVSSA cause UV-sensitive syndrome and destabilize ERCC6 in transcription-coupled DNA repair. Nat Genet 44:593-597. https://doi.org/10.1038/ng.2228

25. Schwertman P, Lagarou A, Dekkers DHW, Raams A, Van Der Hoek AC, Laffeber C, Hoeijmakers JHJ, Demmers JAA, Fousteri M, Vermeulen W, Marteijn JA (2012) UV-sensitive syndrome protein UVSSA recruits USP7 to regulate transcription-coupled repair. Nat Genet 44:598-602. https://doi.org/10.1038/ng.2230

26. Okuda M, Nakazawa Y, Guo C, Ogi T, Nishimura Y (2017) Common TFIIH recruitment mechanism in global genome and transcription-coupled repair subpathways. Nucleic Acids Res 45:13043-13055. https://doi.org/10.1093/nar/gkx970

27. Yokoi M, Masutani C, Maekawa T, Sugasawa K, Ohkuma Y, Hanaoka F (2000) The xeroderma pigmentosum group C protein complex XPC-HR23B plays an important role in the recruitment of transcription factor IIH to damaged DNA. J Biol Chem 275:9870-9875. https://doi.org/10.1074/jbc.275.13.9870

28. van der Weegen Y, Golan-Berman H, Mevissen TET, Apelt K, González-Prieto R, Goedhart J, Heilbrun EE, Vertegaal ACO, van den Heuvel D, Walter JC, Adar S, Luijsterburg MS (2020) The cooperative action of CSB, CSA, and UVSSA target TFIIH to DNA damage-stalled RNA polymerase II. Nat Commun 11:1-16. https://doi.org/10.1038/s41467-020-15903-8

29. Sugasawa K, Akagi J, Nishi R, Iwai S, Hanaoka F (2009) Twostep recognition of DNA damage for mammalian nucleotide excision repair: directional binding of the XPC complex and DNA strand scanning. Mol Cell 36:642-653. https://doi.org/ 10.1016/j.molcel.2009.09.035

30. Compe E, Egly JM (2012) TFIIH: when transcription met DNA repair. Nat Rev Mol Cell Biol 13:343-354

31. Li CL, Golebiowski FM, Onishi Y, Samara NL, Sugasawa K, Yang W (2015) Tripartite DNA lesion recognition and verification by XPC, TFIIH, and XPA in nucleotide excision repair. Mol Cell 59:1025-1034. https://doi.org/10.1016/j.molcel.2015. 08.012

32. Kokic G, Chernev A, Tegunov D, Dienemann C, Urlaub H, Cramer P (2019) Structural basis of TFIIH activation for nucleotide excision repair. Nat Commun 10:2885. https://doi.org/10. 1038/s41467-019-10745-5

33. Coin F, Oksenych V, Mocquet V, Groh S, Blattner C, Egly JM (2008) Nucleotide excision repair driven by the dissociation of CAK from TFIIH. Mol Cell 31:9-20. https://doi.org/10.1016/j. molcel.2008.04.024

34. De Laat WL, Appeldoorn E, Sugasawa K, Weterings E, Jaspers NGJ, Hoeijmakers JHJ (1998) DNA-binding polarity of human replication protein A positions nucleases in nucleotide excision repair. Genes Dev 12:2598-2609. https://doi.org/10.1101/gad. 12.16 .2598

35. Zotter A, Luijsterburg MS, Warmerdam DO, Ibrahim S, Nigg A, van Cappellen WA, Hoeijmakers JHJ, van Driel R, Vermeulen W, Houtsmuller AB (2006) Recruitment of the nucleotide excision repair endonuclease XPG to sites of UV-induced DNA damage depends on functional TFIIH. Mol Cell Biol 26:8868 8879. https://doi.org/10.1128/mcb.00695-06

36. Staresincic L, Fagbemi AF, Enzlin JH, Gourdin AM, Wijgers N, Dunand-Sauthier I, Giglia-Mari G, Clarkson SG, Vermeulen W, Schärer OD (2009) Coordination of dual incision and repair synthesis in human nucleotide excision repair. EMBO J 28:1111-1120. https://doi.org/10.1038/emboj.2009.49

37. Ogi T, Limsirichaikul S, Overmeer RM, Volker M, Takenaka K, Cloney R, Nakazawa Y, Niimi A, Miki Y, Jaspers NG, Mullenders LHF, Yamashita S, Fousteri MI, Lehmann AR (2010) Three DNA polymerases, recruited by different mechanisms, carry out NER repair synthesis in human cells. Mol Cell 37:714-727. https://doi.org/10.1016/j.molcel.2010.02.009

38. Lehmann AR, McGibbon D, Stefanini M (2011) Xeroderma pigmentosum. Orphanet J Rare Dis 6:70

39. Shivji MKK, Wood RD, Podust VN, Hübscher U (1995) Nucleotide excision repair DNA synthesis by DNA polymerase $\epsilon$ in the presence of PCNA, RFC, and RPA. Biochemistry 34:5011-5017. https://doi.org/10.1021/bi00015a012

40. Dehé PM, Gaillard PHL (2017) Control of structure-specific endonucleases to maintain genome stability. Nat Rev Mol Cell Biol 18:315-330

41. Finger LD, Atack JM, Tsutakawa S, Classen S, Tainer J, Grasby J, Shen B (2012) The wonders of flap endonucleases: structure, function, mechanism and regulation. Subcell Biochem 62:301-326. https://doi.org/10.1007/978-94-007-4572-8_16

42. Blanco MG, Matos J (2015) Hold your horSSEs: controlling structure-selective endonucleases MUS81 and Yen1/GEN1. Front Genet 6:253. https://doi.org/10.3389/fgene.2015.00253

43. Sertic S, Quadri R, Lazzaro F, Muzi-Falconi M (2020) EXO1: a tightly regulated nuclease. DNA Repair (Amst) 93:102929. https://doi.org/10.1016/j.dnarep.2020.102929

44. O'Donovan A, Davies AA, Moggs JG, West SC, Wood RD (1994) XPG endonuclease makes the 3' Incision in human DNA nucleotide excision repair. Nature 371:432-435

45. Harrington JJ, Lieber MR (1994) Functional domains within FEN-1 and RAD2 define a family of structure- specific endonucleases: implications for nucleotide excision repair. Genes Dev 8:1344-1355. https://doi.org/10.1101/gad.8.11.1344

46. Evans E, Fellows J, Coffer A, Wood RD (1997) Open complex formation around a lesion during nucleotide excision repair provides a structure for cleavage by human XPG protein. EMBO J 16:625-638. https://doi.org/10.1093/emboj/16.3.625

47. Evans E, Moggs JG, Hwang JR, Egly JM, Wood RD (1997) Mechanism of open complex and dual incision formation by human nucleotide excision repair factors. EMBO J 16:65596573. https://doi.org/10.1093/emboj/16.21.6559

48. Schaeffer L, Roy R, Humbert S, Moncollin V, Vermeulen W, Hoeijmakers JHJ, Chambon P, Egly JM (1993) DNA repair helicase: a component of BTF2 (TFIIH) basic transcription factor. Science (80-) 260:58-63. https://doi.org/10.1126/scien ce. 8465201

49. Hohl M, Thorel F, Clarkson SG, Schärer OD (2003) Structural determinants for substrate binding and catalysis by the structure-specific endonuclease XPG. J Biol Chem 278:1950019508. https://doi.org/10.1074/jbc.M213155200

50. Araújo SJ, Nigg EA, Wood RD (2001) Strong functional interactions of TFIIH with XPC and XPG in human DNA nucleotide excision repair, without a preassembled repairosome. Mol Cell Biol 21:2281-2291. https://doi.org/10.1128/mcb.21.7. 2281-2291.2001

51. Ito S, Kuraoka I, Chymkowitch P, Compe E, Takedachi A, Ishigami C, Coin F, Egly JM, Tanaka K (2007) XPG stabilizes TFIIH, allowing transactivation of nuclear receptors: implications for cockayne syndrome in XP-G/CS patients. Mol Cell 26:231-243. https://doi.org/10.1016/j.molcel.2007.03.013 
52. He Z, Henricksen LA, Wold MS, Ingles CJ (1995) RPA involvement in the damage-recognition and incision steps of nucleotide excision repair. Nature 374:566-569. https://doi. org/10.1038/374566a0

53. Matsunaga T, Park CH, Bessho T, Mu D, Sancar A (1996) Replication protein A confers structure-specific endonuclease activities to the XPF-ERCC1 and XPG subunits of human DNA repair excision nuclease. J Biol Chem 271:11047-11050. https://doi.org/10.1074/jbc.271.19.11047

54. Schärer OD (2008) XPG: its products and biological roles. Adv Exp Med Biol 637:83-92. https://doi.org/10.1007/ 978-0-387-09599-8_9

55. Houle JF, Friedberg EC (1999) The Drosophila ortholog of the human XPG gene. Gene 234:353-360. https://doi.org/10.1016/ S0378-1119(99)00185-7

56. Hofmann K (2009) Ubiquitin-binding domains and their role in the DNA damage response. DNA Repair (Amst) 8:544-556. https://doi.org/10.1016/j.dnarep.2009.01.003

57. Gary R, Ludwig DL, Cornelius HL, MacInnes MA, Park MS (1997) The DNA repair endonuclease XPG binds to proliferating cell nuclear antigen (PCNA) and shares sequence elements with the PCNA-binding regions of FEN-1 and cyclin-dependent kinase inhibitor p21. J Biol Chem 272:24522-24529. https://doi.org/10.1074/jbc.272.39.24522

58. Knauf JA, Pendergrass SH, Marrone BL, Strniste GF, MacInnes MA, Park MS (1996) Multiple nuclear localization signals in XPG nuclease. Mutat Res DNA Repair 363:67-75. https://doi.org/10.1016/0921-8777(95)00062-3

59. Iyer N, Reagan MS, Wu KJ, Canagarajah B, Friedberg EC (1996) Interactions involving the human RNA polymerase II transcription/nucleotide excision repair complex TFIIH, the nucleotide excision repair protein XPG, and Cockayne syndrome group B (CSB) protein. Biochemistry 35:2157-2167. https://doi.org/10. 1021/bi9524124

60. Gervais V, Lamour V, Jawhari A, Frindel F, Wasielewski E, Dubaele S, Egly JM, Thierry JC, Kieffer B, Poterszman A (2004) TFIIH contains a PH domain involved in DNA nucleotide excision repair. Nat Struct Mol Biol 11:616-622. https://doi.org/10. 1038/nsmb782

61. Bardwell AJ, Bardwell L, Iyer N, Svejstrup JQ, Feaver WJ, Kornberg RD, Friedberg EC (1994) Yeast nucleotide excision repair proteins $\operatorname{Rad} 2$ and Rad4 interact with RNA polymerase II basal transcription factor b (TFIIH). Mol Cell Biol 14:3569-3576. https://doi.org/10.1128/mcb.14.6.3569-3576.1994

62. Lafrance-Vanasse J, Arseneault G, Cappadocia L, Chen HT, Pascale L, Omichinski JG (2012) Structural and functional characterization of interactions involving the Tfb1 subunit of TFIIH and the NER factor Rad2. Nucleic Acids Res 40:5739-5750. https:// doi.org/10.1093/nar/gks194

63. Di Lello P, Nguyen BD, Jones TN, Potempa K, Kobor MS, Legault P, Omichinski JG (2005) NMR structure of the aminoterminal domain from the Tfb1 subunit of TFIIH and characterization of its phosphoinositide and VP16 binding sites. Biochemistry 44:7678-7686. https://doi.org/10.1021/bi050099s

64. Thorel F, Constantinou A, Dunand-Sauthier I, Nouspikel T, Lalle P, Raams A, Jaspers NGJ, Vermeulen W, Shivji MKK, Wood RD, Clarkson SG (2004) Definition of a short region of XPG necessary for TFIIH interaction and stable recruitment to sites of UV damage. Mol Cell Biol 24:10670-10680. https://doi.org/ 10.1128/mcb.24.24.10670-10680.2004

65. Dunand-Sauthier I, Hohl M, Thorel F, Jaquier-Gubler P, Clarkson SG, Schärer OD (2005) The spacer region of XPG mediates recruitment to nucleotide excision repair complexes and determines substrate specificity. J Biol Chem 280:7030-7037. https:// doi.org/10.1074/jbc.M412228200
66. Bernardes de Jesus BM, Bjørås M, Coin F, Egly JM (2008) Dissection of the molecular defects caused by pathogenic mutations in the DNA repair factor XPC. Mol Cell Biol 28:7225-7235. https://doi.org/10.1128/mcb.00781-08

67. Riedl T, Hanaoka F, Egly JM (2003) The comings and goings of nucleotide excision repair factors on damaged DNA. EMBO J 22:5293-5303. https://doi.org/10.1093/emboj/cdg489

68. Wakasugi M, Sancar A (1998) Assembly, subunit composition, and footprint of human DNA repair excision nuclease. Proc Natl Acad Sci USA 12:6669-6674

69. Lafrance-Vanasse J, Arseneault GV, Cappadocia L, Legault P, Omichinski JG (2013) Structural and functional evidence that Rad4 competes with Rad2 for binding to the Tfb1 subunit of TFIIH in NER. Nucleic Acids Res 41:2736-2745. https://doi. org/10.1093/nar/gks1321

70. Okuda M, Kinoshita M, Kakumu E, Sugasawa K, Nishimura Y (2015) Structural insight into the mechanism of TFIIH recognition by the acidic string of the nucleotide excision repair factor XPC. Structure 23:1827-1837. https://doi.org/10.1016/j.str.2015. 07.009

71. Van Cuijk L, Van Belle GJ, Turkyilmaz Y, Poulsen SL, Janssens RC, Theil AF, Sabatella M, Lans H, Mailand N, Houtsmuller AB, Vermeulen W, Marteijn JA (2015) SUMO and ubiquitindependent XPC exchange drives nucleotide excision repair. Nat Commun 6:7499. https://doi.org/10.1038/ncomms8499

72. Tsutakawa SE, Sarker AH, Ng C, Arvai AS, Shin DS, Shih B, Jiang S, Thwin AC, Tsai MS, Willcox A, Her MZ, Trego KS, Raetz AG, Rosenberg D, Bacolla A, Hammel M, Griffith JD, Cooper PK, Tainer JA (2020) Human XPG nuclease structure, assembly, and activities with insights for neurodegeneration and cancer from pathogenic mutations. Proc Natl Acad Sci USA 117:14127-14138. https://doi.org/10.1073/pnas.19213 11117

73. Sarker AH, Tsutakawa SE, Kostek S, Ng C, Shin DS, Peris M, Campeau E, Tainer JA, Nogales E, Cooper PK (2005) Recognition of RNA polymerase II and transcription bubbles by XPG, CSB, and TFIIH: Insights for transcription-coupled repair and Cockayne syndrome. Mol Cell 20:187-198. https://doi.org/10. 1016/j.molcel.2005.09.022

74. Okuda M, Suwa T, Suzuki H, Yamaguchi Y, Nishimura Y (2021) Three human RNA polymerases interact with TFIIH via a common RPB6 subunit. Nucleic Acids Res 50:1-16. https://doi.org/ 10.1093/nar/gkab612

75. Miętus M, Nowak E, Jaciuk M, Kustosz P, Studnicka J, Nowotny M (2014) Crystal structure of the catalytic core of Rad 2: insights into the mechanism of substrate binding. Nucleic Acids Res 42:10762-10775. https://doi.org/10.1093/nar/gku729

76. González-Corrochano R, Ruiz FM, Taylor NMI, Huecas S, Drakulic S, Spínola-Amilibia M, Fernández-Tornero C (2020) The crystal structure of human XPG, the xeroderma pigmentosum group $\mathrm{G}$ endonuclease, provides insight into nucleotide excision DNA repair. Nucleic Acids Res 48:9943-9958. https://doi.org/ 10.1093/nar/gkaa688

77. Constantinou A, Gunz D, Evans E, Lalle P, Bates PA, Wood RD, Clarkson SG (1999) Conserved residues of human XPG protein important for nuclease activity and function in nucleotide excision repair. J Biol Chem 274:5637-5648. https://doi.org/10.1074/ jbc.274.9.5637

78. Wakasugi M, Reardon JT, Sancar A (1997) The Non-catalytic function of XPG protein during dual incision in human nucleotide excision repair. J Biol Chem 272:16030-16034. https://doi. org/10.1074/jbc. 272.25 .16030

79. Puumalainen MR, Lessel D, Rüthemann P, Kaczmarek N, Bachmann K, Ramadan K, Naegeli H (2014) Chromatin retention of DNA damage sensors DDB2 and XPC through loss of p97 
segregase causes genotoxicity. Nat Commun 5:3695. https://doi. org/10.1038/ncomms4695

80. Kemp MG, Reardon JT, Lindsey-Boltz LA, Sancar A (2012) Mechanism of release and fate of excised oligonucleotides during nucleotide excision repair. J Biol Chem 287:22889-22899. https://doi.org/10.1074/jbc.M112.374447

81. Hu J, Choi JH, Gaddameedhi S, Kemp MG, Reardon JT, Sancar A (2013) Nucleotide excision repair in human cells: Fate of the excised oligonucleotide carrying dna damage in vivo. $\mathbf{J}$ Biol Chem 288:20918-20926. https://doi.org/10.1074/jbc.M113. 482257

82. Mocquet V, Lainé JP, Riedl T, Yajin Z, Lee MY, Egly JM (2008) Sequential recruitment of the repair factors during NER: the role of XPG in initiating the resynthesis step. EMBO J 27:155-167. https://doi.org/10.1038/sj.emboj.7601948

83. Essers J, Theil AF, Baldeyron C, van Cappellen WA, Houtsmuller AB, Kanaar R, Vermeulen W (2005) Nuclear dynamics of PCNA in DNA replication and repair. Mol Cell Biol 25:9350-9359. https://doi.org/10.1128/mcb.25.21.9350-9359.2005

84. Gilljam KM, Müller R, Liabakk NB, Otterlei M (2012) Nucleotide excision repair is associated with the replisome and its efficiency depends on a direct interaction between XPA and PCNA. PLoS ONE 7:e49199. https://doi.org/10.1371/journal.pone. 0049199

85. Araújo SJ, Tirode F, Coin F, Pospiech H, Syväoja JE, Stucki M, Hübscher U, Egly JM, Wood RD (2000) Nucleotide excision repair of DNA with recombinant human proteins: definition of the minimal set of factors, active forms of TFIIH, and modulation by CAK. Genes Dev 14:349-359. https://doi.org/10.5167/ uzh-845

86. Overmeer RM, Gourdin AM, Giglia-Mari A, Kool H, Houtsmuller AB, Siegal G, Fousteri MI, Mullenders LHF, Vermeulen W (2010) Replication factor $C$ recruits dna polymerase $\delta$ to sites of nucleotide excision repair but is not required for PCNA recruitment. Mol Cell Biol 30:4828-4839. https://doi.org/10.1128/mcb. 00285-10

87. Han C, Wan G, Zhao R, Qian J, Sharma N, He J, Zhu Q, Wang QE, Wani AA (2015) Cdt2-mediated xpg degradation promotes gap-filling DNA synthesis in nucleotide excision repair. Cell Cycle 14:1103-1115. https://doi.org/10.4161/15384101.2014. 973740

88. Povlsen LK, Beli P, Wagner SA, Poulsen SL, Sylvestersen KB, Poulsen JW, Nielsen ML, Bekker-Jensen S, Mailand N, Choudhary C (2012) Systems-wide analysis of ubiquitylation dynamics reveals a key role for PAF15 ubiquitylation in DNA-damage bypass. Nat Cell Biol 14:1089-1098. https://doi.org/10.1038/ ncb2579

89. Elia AEH, Boardman AP, Wang DC, Huttlin EL, Everley RA, Dephoure N, Zhou C, Koren I, Gygi SP, Elledge SJ (2015) Quantitative proteomic atlas of ubiquitination and acetylation in the DNA damage response. Mol Cell 59:867-881. https://doi.org/10. 1016/j.molcel.2015.05.006

90. Le May N, Mota-Fernandes D, Vélez-Cruz R, Iltis I, Biard D, Egly JM (2010) NER factors are recruited to active promoters and facilitate chromatin modification for transcription in the absence of exogenous genotoxic attack. Mol Cell 38:54-66. https://doi.org/10.1016/j.molcel.2010.03.004

91. Le May N, Fradin D, Iltis I, Bougnères P, Egly JM (2012) XPG and XPF endonucleases trigger chromatin looping and DNA demethylation for accurate expression of activated genes. Mol Cell 47:622-632. https://doi.org/10.1016/j.molcel.2012.05.050

92. Eyboulet F, Cibot C, Eychenne T, Neil H, Alibert O, Werner M, Soutourina J (2013) Mediator links transcription and DNA repair by facilitating Rad2/XPG recruitment. Genes Dev 27:2549-2562. https://doi.org/10.1101/gad.225813.113
93. Georges A, Gopaul D, Denby Wilkes C, GiordanengoAiach N, Novikova E, Barrault MB, Alibert O, Soutourina J (2019) Functional interplay between Mediator and RNA polymerase II in Rad2/XPG loading to the chromatin. Nucleic Acids Res 47:8988-9004. https://doi.org/10.1093/nar/gkz598

94. Kumar N, Raja S, Van Houten B (2020) The involvement of nucleotide excision repair proteins in the removal of oxidative DNA damage. Nucleic Acids Res 48:11227-11243. https://doi. org/10.1093/nar/gkaa777

95. Menoni H, Wienholz F, Theil AF, Janssens RC, Lans H, Campalans A, Radicella JP, Marteijn JA, Vermeulen W (2018) The transcription-coupled DNA repair-initiating protein CSB promotes XRCC1 recruitment to oxidative DNA damage. Nucleic Acids Res 46:7747-7756. https://doi.org/10.1093/nar/gky579

96. Menoni H, Hoeijmakers JHJ, Vermeulen W (2012) Nucleotide excision repair-initiating proteins bind to oxidative DNA lesions in vivo. J Cell Biol 199:1037-1046. https://doi.org/10.1083/jcb. 201205149

97. Ranes M, Boeing S, Wang Y, Wienholz F, Menoni H, Walker J, Encheva V, Chakravarty P, Mari PO, Stewart A, Giglia-Mari G, Snijders AP, Vermeulen W, Svejstrup JQ (2016) A ubiquitylation site in Cockayne syndrome B required for repair of oxidative DNA damage, but not for transcription-coupled nucleotide excision repair. Nucleic Acids Res 44:5246-5255. https://doi.org/10. 1093/nar/gkw216

98. Jang S, Kumar N, Beckwitt EC, Kong M, Fouquerel E, RapićOtrin V, Prasad R, Watkins SC, Khuu C, Majumdar C, David SS, Wilson SH, Bruchez MP, Opresko PL, Van Houten B (2019) Damage sensor role of UV-DDB during base excision repair. Nat Struct Mol Biol 26:695-703. https://doi.org/10.1038/ s41594-019-0261-7

99. Shimizu Y, Uchimura Y, Dohmae N, Saitoh H, Hanaoka F, Sugasawa K (2010) Stimulation of DNA glycosylase activities by XPC protein complex: Roles of protein-protein interactions. J Nucleic Acids 2010:805698. https://doi.org/10.4061/2010/ 805698

100. Wang HT, Choi B, Tang MS (2010) Melanocytes are deficient in repair of oxidative DNA damage and UV-induced photoproducts. Proc Natl Acad Sci USA 107:12180-12185. https://doi.org/10. 1073/pnas. 1005244107

101. Klungland A, Höss M, Gunz D, Constantinou A, Clarkson SG, Doetsch PW, Bolton PH, Wood RD, Lindahl T (1999) Base excision repair of oxidative DNA damage activated by XPG protein. Mol Cell 3:33-42. https://doi.org/10.1016/S1097-2765(00) 80172-0

102. Bessho T (1999) Nucleotide excision repair 3' endonuclease XPG stimulates the activity of base excision repair enzyme thymine glycol DNA glycosylase. Nucleic Acids Res 27:979-983. https://doi.org/10.1093/nar/27.4.979

103. Limpose KL, Trego KS, Li Z, Leung SW, Sarker AH, Shah JA, Ramalingam SS, Werner EM, Dynan WS, Cooper PK, Corbett AH, Doetsch PW (2018) Overexpression of the base excision repair NTHL1 glycosylase causes genomic instability and early cellular hallmarks of cancer. Nucleic Acids Res 46:4515-4532. https://doi.org/10.1093/nar/gky162

104. García-Muse T, Aguilera A (2019) R loops: from physiological to pathological roles. Cell 179:604-618. https://doi.org/10.1016/j. cell.2019.08.055

105. Marnef A, Legube G (2021) R-loops as Janus-faced modulators of DNA repair. Nat Cell Biol 23:305-313. https://doi.org/10. 1038/s41556-021-00663-4

106. Tresini M, Warmerdam DO, Kolovos P, Snijder L, Vrouwe MG, Demmers JAA, Van Ijcken WFJ, Grosveld FG, Medema RH, Hoeijmakers JHJ, Mullenders LHF, Vermeulen W, Marteijn JA (2015) The core spliceosome as target and effector of 
non-canonical ATM signalling. Nature 523:53-58. https://doi. org/10.1038/nature 14512

107. Tian M, Alt FW (2000) Transcription-induced cleavage of Immunoglobulin switch regions by nucleotide excision repair nucleases in vitro. J Biol Chem 275:24163-24172. https://doi.org/10.1074/ jbc.M003343200

108. Sollier J, Stork CT, García-Rubio ML, Paulsen RD, Aguilera A, Cimprich KA (2014) Transcription-coupled nucleotide excision repair factors promote R-loop-induced genome instability. Mol Cell 56:777-785. https://doi.org/10.1016/j.molcel.2014.10.020

109. Freudenreich CH (2018) R-loops: targets for nuclease cleavage and repeat instability. Curr Genet 64:789-794. https://doi.org/ 10.1007/s00294-018-0806-Z

110. He Y, Pasupala N, Zhi H, Dorjbal B, Hussain I, Shih HM, Bhattacharyya S, Biswas R, Miljkovic M, Semmes OJ, Waldmann TA, Snow AL, Giam CZ (2021) NF-KB-induced R-loop accumulation and DNA damage select for nucleotide excision repair deficiencies in adult T cell leukemia. Proc Natl Acad Sci USA 118:e2005568118. https://doi.org/10.1073/pnas.2005568118

111. Yasuhara T, Kato R, Hagiwara Y, Shiotani B, Yamauchi M, Nakada S, Shibata A, Miyagawa K (2018) Human Rad52 promotes XPG-mediated R-loop processing to initiate transcriptionassociated homologous recombination repair. Cell 175:558-570. e11. https://doi.org/10.1016/j.cell.2018.08.056

112. Goulielmaki E, Tsekrekou M, Batsiotos N, Ascensão-Ferreira M, Ledaki E, Stratigi K, Chatzinikolaou G, Topalis P, Kosteas T, Altmüller J, Demmers JA, Barbosa-Morais NL, Garinis GA (2021) The splicing factor XAB2 interacts with ERCC1-XPF and XPG for R-loop processing. Nat Commun 12:3153. https://doi. org/10.1038/s41467-021-23505-1

113. Scalera C, Ticli G, Dutto I, Cazzalini O, Stivala LA, Prosperi E (2021) Transcriptional stress induces chromatin relocation of the nucleotide excision repair factor XPG. Int J Mol Sci 22:6589. https://doi.org/10.3390/ijms22126589

114. Cristini A, Ricci G, Britton S, Salimbeni S, Huang S, Yin N, Marinello J, Calsou P, Pommier Y, Favre G, Capranico G, Gromak N, Sordet O (2019) Dual processing of R-loops and topoisomerase I induces transcription-dependent DNA double-strand breaks. Cell Rep 28:3167-3181.e6. https://doi.org/10.1016/j. celrep.2019.08.041

115. Marabitti V, Lillo G, Malacaria E, Palermo V, Sanchez M, Pichierri P, Franchitto A (2019) ATM pathway activation limits R-loop-associated genomic instability in Werner syndrome cells. Nucleic Acids Res 47:3485-3502. https://doi.org/10.1093/nar/ gkz025

116. Trego KS, Chernikova SB, Davalos AR, Perry JJP, Finger LD, $\mathrm{Ng} \mathrm{C}$, Tsai MS, Yannone SM, Tainer JA, Campisi J, Cooper PK (2011) The DNA repair endonuclease XPG interacts directly and functionally with the WRN helicase defective in Werner syndrome. Cell Cycle 10:1998-2007. https://doi.org/10.4161/cc.10. 12.15878

117. Trego KS, Groesser T, Davalos AR, Parplys AC, Zhao W, Nelson MR, Hlaing A, Shih B, Rydberg B, Pluth JM, Tsai MS, Hoeijmakers JHJ, Sung P, Wiese C, Campisi J, Cooper PK (2016) Non-catalytic roles for XPG with BRCA1 and BRCA2 in homologous recombination and genome stability. Mol Cell 61:535-546. https://doi.org/10.1016/j.molcel.2015.12.026

118. Natale V, Raquer H (2017) Xeroderma pigmentosum-Cockayne syndrome complex. Orphanet J Rare Dis 12:65

119. Lans H, Lindvall JM, Thijssen K, Karambelas AE, Cupac D, Fensgård O, Jansen G, Hoeijmakers JHJ, Nilsen H, Vermeulen W (2013) DNA damage leads to progressive replicative decline but extends the life span of long-lived mutant animals. Cell Death Differ 20:1709-1718. https://doi.org/10.1038/cdd.2013.126

120. Lee SK, Yu SL, Prakash L, Prakash S (2002) Requirement of yeast RAD2, a homolog of human XPG gene, for efficient
RNA polymerase II transcription: implications for Cockayne syndrome. Cell 109:823-834. https://doi.org/10.1016/S00928674(02)00795-X

121. Harada Y-N, Shiomi N, Koike M, Ikawa M, Okabe M, Hirota S, Kitamura Y, Kitagawa M, Matsunaga T, Nikaido O, Shiomi T (1999) Postnatal growth failure, short life span, and early onset of cellular senescence and subsequent immortalization in mice lacking the xeroderma pigmentosum group $\mathrm{G}$ gene. Mol Cell Biol 19:2366-2372. https://doi.org/10.1128/mcb.19.3.2366

122. Shiomi N, Kito S, Oyama M, Matsunaga T, Harada Y-N, Ikawa M, Okabe M, Shiomi T (2004) Identification of the XPG region that causes the onset of Cockayne syndrome by using Xpg mutant mice generated by the cDNA-mediated knock-in method. Mol Cell Biol 24:3712-3719. https://doi.org/10.1128/mcb.24.9. 3712-3719.2004

123. Tian M, Jones DA, Smith M, Shinkura R, Alt FW (2004) Deficiency in the nuclease activity of xeroderma pigmentosum $\mathrm{G}$ in mice leads to hypersensitivity to UV irradiation. Mol Cell Biol 24:2237-2242. https://doi.org/10.1128/mcb.24.6.2237-2242. 2004

124. Barnhoorn S, Uittenboogaard LM, Jaarsma D, Vermeij WP, Tresini M, Weymaere M, Menoni H, Brandt RMC, de Waard MC, Botter SM, Sarker AH, Jaspers NGJ, van der Horst GTJ, Cooper PK, Hoeijmakers JHJ, van der Pluijm I (2014) Cell-autonomous progeroid changes in conditional mouse models for repair endonuclease XPG deficiency. PLoS Genet 10:e1004686. https://doi. org/10.1371/journal.pgen.1004686

125. Kajitani GS, de Nascimento LLS, de Neves MRC, da Leandro GS, Garcia CCM, Menck CFM (2021) Transcription blockage by DNA damage in nucleotide excision repair-related neurological dysfunction. Semin Cell Dev Biol 114:20-35. https://doi.org/10. 1016/J.SEMCDB.2020.10.009

126. Dianov G, Bischoff C, Sunesen M, Bohr VA (1999) Repair of 8-oxoguanine in DNA is deficient in Cockayne syndrome group B cells. Nucleic Acids Res 27:1365-1368. https://doi.org/10. 1093/NAR/27.5.1365

127. Tuo J, Jaruga P, Rodriguez H, Bohr VA, Dizdaroglu M (2003) Primary fibroblasts of Cockayne syndrome patients are defective in cellular repair of 8-hydroxyguanine and 8-hydroxyadenine resulting from oxidative stress. FASEB J 17:668-674. https://doi. org/10.1096/FJ.02-0851COM

128. D'Errico M, Parlanti E, Teson M, Degan P, Lemma T, Calcagnile A, Iavarone I, Jaruga P, Ropolo M, Pedrini AM, Orioli D, Frosina G, Zambruno G, Dizdaroglu M, Stefanini M, Dogliotti E (2007) The role of CSA in the response to oxidative DNA damage in human cells. Oncogene 26:4336-4343. https://doi.org/10.1038/ SJ.ONC.1210232

129. Thorslund T, von Kobbe C, Harrigan JA, Indig FE, Christiansen M, Stevnsner T, Bohr VA (2005) Cooperation of the Cockayne syndrome group B protein and poly(ADP-ribose) polymerase 1 in the response to oxidative stress. Mol Cell Biol 25:7625-7636. https://doi.org/10.1128/MCB.25.17.7625-7636.2005

130. Wong HK, Muftuoglu M, Beck G, Imam SZ, Bohr VA, Wilson DM (2007) Cockayne syndrome B protein stimulates apurinic endonuclease 1 activity and protects against agents that introduce base excision repair intermediates. Nucleic Acids Res 35:41034113. https://doi.org/10.1093/NAR/GKM404

131. D'Errico M, Pascucci B, Iorio E, Van Houten B, Dogliotti E (2013) The role of CSA and CSB protein in the oxidative stress response. Mech Ageing Dev 134:261-269. https://doi.org/10. 1016/J.MAD.2013.03.006

132. Sabatella M, Theil AF, Ribeiro-Silva C, Slyskova J, Thijssen K, Voskamp C, Lans H, Vermeulen W (2018) Repair protein persistence at DNA lesions characterizes XPF defect with Cockayne syndrome features. Nucleic Acids Res 46:9563-9577. https://doi. org/10.1093/nar/gky774 
133. Wang T, Xu C, Zhou XP, Lee JJ, Shen J, Lian BQ, Liu YH, Lian CG (2015) Novel germline ERCC5 mutations identified in a xeroderma pigmentosum complementation group $\mathrm{G}$ pedigree. JAAD Case Rep 1:66-70. https://doi.org/10.1016/j.jdcr.2014.12. 004

134. Soltys DT, Rocha CRR, Lerner LK, de Souza TA, Munford V, Cabral F, Nardo T, Stefanini M, Sarasin A, Cabral-Neto JB, Menck CFM (2013) Novel XPG (ERCC5) mutations affect DNA repair and cell survival after ultraviolet but not oxidative stress. Hum Mutat 34:481-489. https://doi.org/10.1002/humu.22259

135. Sun Z, Zhang J, Guo Y, Ni C, Liang J, Cheng R, Li M, Yao Z (2015) Genotype-phenotype correlation of xeroderma pigmentosum in a Chinese Han population. Br J Dermatol 172:1096-1102. https://doi.org/10.1111/bjd.13429

136. Moriwaki S, Takigawa M, Igarashi N, Nagai Y, Amano H, Ishikawa O, Khan SG, Kraemer KH (2012) Xeroderma pigmentosum complementation group $\mathrm{G}$ patient with a novel homozygous missense mutation and no neurological abnormalities. Exp Dermatol 21:304-307. https://doi.org/10.1111/j.1600-0625.2012.01446.x

137. Emmert S, Slor H, Busch DB, Batko S, Albert RB, Coleman D, Khan SG, Abu-Libdeh B, DiGiovanna JJ, Cunningham BB, Lee MM, Crollick J, Inui H, Ueda T, Hedayati M, Grossman L, Shahlavi T, Cleaver JE, Kraemer KH (2002) Relationship of neurologic degeneration to genotype in three xeroderma pigmentosum group G patients. J Invest Dermatol 118:972-982. https:// doi.org/10.1046/j.1523-1747.2002.01782.x

138. Zhou EY, Wang H, Lin Z, Xu G, Ma Z, Zhao J, Feng C, Duo L, Yin J, Yang Y (2017) Clinical and molecular epidemiological study of xeroderma pigmentosum in China: a case series of 19 patients. J Dermatol 44:71-75. https://doi.org/10.1111/13468138.13576

139. Fassihi H, Sethi M, Fawcett H, Wing J, Chandler N, Mohammed S, Craythorne E, Morley AMS, Lim R, Turner S, Henshaw T, Garrood I, Giunti P, Hedderly T, Abiona A, Naik H, Harrop G, McGibbon D, Jaspers NGJ, Botta E, Nardo T, Stefanini M, Young AR, Sarkany RPE, Lehmann AR (2016) Deep phenotyping of 89 xeroderma pigmentosum patients reveals unexpected heterogeneity dependent on the precise molecular defect. Proc Natl Acad Sci USA 113:E1236-E1245. https://doi.org/10.1073/ pnas. 1519444113

140. Chikhaoui A, Elouej S, Nabouli I, Jones M, Lagarde A, Ben RM, Messaoud O, Hamdi Y, Zghal M, Delague V, Levy N, De Sandre-Giovannoli A, Abdelhak S, Yacoub-Youssef H (2019) Identification of a ERCC5 c.2333T >C (L778P) variant in two Tunisian siblings with mild xeroderma pigmentosum phenotype. Front Genet 10:1-8. https://doi.org/10.3389/fgene.2019.00111

141. Fischer E, Thielmann HW, Neundörfer B, Rentsch FJ, Edler L, Jung EG (1982) Xeroderma pigmentosum patients from Germany: clinical symptoms and DNA repair characteristics. Arch Dermatol Res 274:229-247. https://doi.org/10.1007/BF004 03726

142. Norris PG, Hawk JLM, Avery JA, Giannelli F (1987) Xeroderma pigmentosum complementation group $\mathrm{G}$-report of two cases. Br J Dermatol 116:861-866. https://doi.org/10.1111/j.13652133.1987.tb04906.x

143. Shah K, Mehmood S, Jan A, Abbe I, Hussain Ali R, Khan A, Chishti MS, Lee K, Ahmad F, Ansar M, Shahzad S, Nickerson DA, Bamshad MJ, Coucke PJ, Santos-Cortez RLP, Spritz RA, Leal SM, Ahmad W (2017) Sequence variants in nine different genes underlying rare skin disorders in 10 consanguineous families. Int J Dermatol 56:1406-1413. https://doi.org/10.1111/ ijd.13778

144. Ichihashi M, Fujiwara Y, Uehara Y, Matsumoto A (1985) A mild form of xeroderma pigmentosum assigned to complementation group G and its repair heterogeneity. J Invest Dermatol 85:284287. https://doi.org/10.1111/1523-1747.ep12276776

145. Yoneda K, Moriue J, Matsuoka Y, Moriwaki SI, Moriue T, Nakai K, Yokoi I, Nibu N, Demitsu T, Kubota Y (2007) Xeroderma pigmentosum complementation group $\mathrm{G}$ in association with malignant melanoma [4]. Eur J Dermatol 17:540-541. https:// doi.org/10.1684/ejd.2007.0275

146. Moriwaki SI, Stefanini M, Lehmann AR, Hoeijmakers JHJ, Robbins JH, Rapin I, Botta E, Tanganelli B, Vermeulen W, Broughton BC, Kraemer KH (1996) DNA repair and ultraviolet mutagenesis in cells from a new patient with Xeroderma pigmentosum group $\mathrm{G}$ and Cockayne syndrome resemble Xeroderma pigmentosum cells. J Invest Dermatol 107:647-653. https://doi. org/10.1111/1523-1747.ep12584287

147. Okinaka RT, Perez-Castro AV, Sena A, Laubscher K, Strniste GF, Park MS, Hernandez R, MacInnes MA, Kraemer KH (1997) Heritable genetic alterations in a xeroderma pigmentosum group $\mathrm{G} /$ Cockayne syndrome pedigree. Mutat Res DNA Repair 385:107114. https://doi.org/10.1016/S0921-8777(97)00031-1

148. Lindenbaum Y, Dickson D, Rosenbaum P, Kraemer K, Robbins J, Rapin I (2001) Xeroderma pigmentosum/Cockayne syndrome complex: first neuropathological study and review of eight other cases. Eur J Paediatr Neurol 5:225-242. https://doi.org/10.1053/ ejpn.2001.0523

149. Lehmann J, Schubert S, Schäfer A, Apel A, Laspe P, Schiller S, Ohlenbusch A, Gratchev A, Emmert S (2014) An unusual mutation in the XPG gene leads to an internal in-frame deletion and a XP/CS complex phenotype. Br J Dermatol 171:903-905. https:// doi.org/10.1111/bjd.13035

150. Zhang J, Cheng R, Yu X, Sun Z, Li M, Yao Z (2017) Expansion of the genotypic and phenotypic spectrum of xeroderma pigmentosum in Chinese population. Photodermatol Photoimmunol Photomed 33:58-63. https://doi.org/10.1111/phpp.12283

151. Yang Y, Yao X, Luo Y, Zhao L, Zhou B, Tu M, Zhao R (2017) Identification of a novel mutation confirms phenotypic variability of mutant XPG truncations. Int J Dermatol 56:e149e151. https://doi.org/10.1111/ijd.13554

152. Al-Shamsi A, Hertecant JL, Souid AK, Al-Jasmi FA (2016) Whole exome sequencing diagnosis of inborn errors of metabolism and other disorders in United Arab Emirates. Orphanet J Rare Dis 11:94. https://doi.org/10.1186/s13023-016-0474-3

153. Wojcik MH, Schwartz TS, Thiele KE, Paterson H, Stadelmaier R, Mullen TE, VanNoy GE, Genetti CA, Madden JA, Gubbels CS, Yu TW, Tan WH, Agrawal PB (2019) Infant mortality: the contribution of genetic disorders. J Perinatol 39:1611-1619. https://doi.org/10.1038/s41372-019-0451-5

154. Zafeiriou DI, Thorel F, Andreou A, Kleijer WJ, Raams A, Garritsen VH, Gombakis N, Jaspers NGJ, Clarkson SG (2001) Xeroderma pigmentosum group $\mathrm{G}$ with severe neurological involvement and features of Cockayne syndrome in infancy. Pediatr Res 49:407-412. https://doi.org/10.1203/00006450200103000-00016

155. Schäfer A, Schubert S, Gratchev A, Seebode C, Apel A, Laspe P, Hofmann L, Ohlenbusch A, Mori T, Kobayashi N, Schürer A, Schön MP, Emmert S (2013) Characterization of three XPG-defective patients identifies three missense mutations that impair repair and transcription. J Invest Dermatol 133:1841-1849. https://doi.org/10.1038/jid.2013.54

156. Santiago KM, Castro LP, Neto JPD, de Nóbrega AF, Pinto CAL, Ashton-Prolla P, Pinto e Vairo F, de Medeiros PFV, Ribeiro EM, Ribeiro BFR, do Valle FF, Doriqui MJR, Leite CHB, Rocha RM, Moura LMS, Munford V, Galante PAF, Menck CFM, Rogatto SR, Achatz MI (2020) Comprehensive germline mutation analysis and clinical profile in a large cohort of Brazilian xeroderma pigmentosum patients. J Eur Acad 
Dermatol Venereol 34:2392-2401. https://doi.org/10.1111/ jdv. 16405

157. Vermeulen W, Jaeken J, Jaspers NGJ, Bootsma D, Hoeijmakers JHJ (1993) Xeroderma pigmentosum complementation group $\mathrm{G}$ associated with Cockayne syndrome. Am J Hum Genet 53:185-192

158. Jacken J, Klocker H, Schwaiger H, Bellmann R, Hirsch-Kauffmann M, Schweiger M (1989) Clinical and biochemical studies in three patients with severe early infantile Cockayne syndrome. Hum Genet 83:339-346. https://doi.org/10.1007/BF00291378

159. Ricotti R, Nardo T, Striano P, Stefanini M, Orioli D, Botta E (2018) Phenotypic variability in xeroderma pigmentosum group G: an uncommon case with severe prenatal-onset Cockayne syndrome features. Clin Genet 94:386-388. https://doi.org/10.1111/ cge. 13364

160. Lalle P, Nouspikel T, Constantinou A, Thorel F, Clarkson SG (2002) The founding members of xeroderma pigmentosum group $\mathrm{G}$ produce XPG protein with severely impaired endonuclease activity. J Invest Dermatol 118:344-351. https://doi.org/10. 1046/j.0022-202x.2001.01673.x

161. Keijzer W, Jaspers NGJ, Abrahams PJ, Taylor AMR, Arlett CF, Zelle B, Takebe H, Kinmont PDS, Bootsma D (1979) A seventh complementation group in excision-deficient xeroderma pigmentosum. Mutat Res Fundam Mol Mech Mutagen 62:183-190. https://doi.org/10.1016/0027-5107(79)90231-8

162. Arlett CF, Harcourt SA, Lehmann AR, Stevens S, Fergusonsmith MA, Morley WN (1980) Studies on a new case of xeroderma pigmentosum (XP3BR) from complementation group $g$ with cellular sensitivity to ionizing radiation. Carcinogenesis 1:745-751. https://doi.org/10.1093/carcin/1.9.745

163. Calmels N, Greff G, Obringer C, Kempf N, Gasnier C, Tarabeux J, Miguet M, Baujat G, Bessis D, Bretones P, Cavau A, Digeon B, Doco-Fenzy M, Doray B, Feillet F, Gardeazabal J, Gener B, Julia S, Llano-Rivas I, Mazur A, Michot C, Renaldo-Robin F, Rossi M, Sabouraud P, Keren B, Depienne C, Muller J, Mandel JL, Laugel V (2016) Uncommon nucleotide excision repair phenotypes revealed by targeted high-throughput sequencing. Orphanet J Rare Dis 11:26. https://doi.org/10.1186/s13023-016-0408-0

164. Hijazi H, Salih MA, Hamad MHA, Hassan HH, Salih SBM, Mohamed KA, Mukhtar MM, Karrar ZA, Ansari S, Ibrahim N, Alkuraya FS (2015) Pellagra-like condition is xeroderma pigmentosum/Cockayne syndrome complex and niacin confers clinical benefit. Clin Genet 87:56-61. https://doi.org/10.1111/ cge. 12325

165. Hamel BCJ, Raams A, Schuitema-Dijkstra AR, Simons P, Van Der Burgt I, Jaspers NGJ, Kleijer WJ (1996) Xeroderma pigmentosum-Cockayne syndrome complex: a further case. J Med Genet 33:607-610. https://doi.org/10.1136/jmg.33.7.607

166. Le Van QP, Calmels N, Bonnière M, Chartier S, Razavi F, Chelly J, El Chehadeh S, Baer S, Boutaud L, Bacrot S, Obringer C, Favre R, Attié-Bitach T, Laugel V, Antal MC (2020) Prenatal diagnosis of cerebro-oculo-facio-skeletal syndrome: report of three fetuses and review of the literature. Am J Med Genet Part A 182:1236-1242. https://doi.org/10.1002/ajmg.a.61520

167. Drury S, Boustred C, Tekman M, Stanescu H, Kleta R, Lench N, Chitty LS, Scott RH (2014) A novel homozygous ERCC5 truncating mutation in a family with prenatal arthrogryposis-further evidence of genotype-phenotype correlation. Am J Med Genet Part A 164:1777-1783. https://doi.org/10.1002/ajmg.a.36506
168. Baer S, Obringer C, Julia S, Chelly J, Capri Y, Gras D, Baujat G, Felix TM, Doray B, Sanchez del Pozo J, Ramos LM, Burglen L, Laugel V, Calmels N (2020) Early-onset nucleotide excision repair disorders with neurological impairment: clues for early diagnosis and prognostic counseling. Clin Genet 98:251-260. https://doi.org/10.1111/cge. 13798

169. Deden C, Neveling K, Zafeiropopoulou D, Gilissen C, Pfundt R, Rinne T, de Leeuw N, Faas B, Gardeitchik T, Sallevelt SCEH, Paulussen A, Stevens SJC, Sikkel E, Elting MW, van Maarle MC, Diderich KEM, Corsten-Janssen N, Lichtenbelt KD, Lachmeijer G, Vissers LELM, Yntema HG, Nelen M, Feenstra I, van ZelstStams WAG (2020) Rapid whole exome sequencing in pregnancies to identify the underlying genetic cause in fetuses with congenital anomalies detected by ultrasound imaging. Prenat Diagn 40:972-983. https://doi.org/10.1002/pd.5717

170. Panigrahi I, Shankar Prasad BA, Kaur H, Kalra J (2021) COFS type 3 in an Indian family with antenatally detected arthrogryposis. Am J Med Genet Part A 185:631-635. https://doi.org/10. 1002/ajmg.a.61979

171. Kvarnung M, Taylan F, Nilsson D, Anderlid BM, Malmgren H, Lagerstedt-Robinson K, Holmberg E, Burstedt M, Nordenskjöld M, Nordgren A, Lundberg ES (2018) Genomic screening in rare disorders: new mutations and phenotypes, highlighting ALG14 as a novel cause of severe intellectual disability. Clin Genet 94:528-537. https://doi.org/10.1111/cge.13448

172. Monies D, Abouelhoda M, Assoum M, Moghrabi N, Rafiullah R, Almontashiri N, Alowain M, Alzaidan H, Alsayed M, Subhani S, Cupler E, Faden M, Alhashem A, Qari A, Chedrawi A, Aldhalaan H, Kurdi W, Khan S, Rahbeeni Z, Alotaibi M, Goljan E, Elbardisy H, ElKalioby M, Shah Z, Alruwaili H, Jaafar A, Albar R, Akilan A, Tayeb H, Tahir A, Fawzy M, Nasr M, Makki S, Alfaifi A, Akleh H, Yamani S, Bubshait D, Mahnashi M, Basha T, Alsagheir A, Abu Khaled M, Alsaleem K, Almugbel M, Badawi M, Bashiri F, Bohlega S, Sulaiman R, Tous E, Ahmed S, Algoufi T, Al-Mousa H, Alaki E, Alhumaidi S, Althagafi M, Alghamdi H, Alghamdi M, Sahly A, Nahrir S, Al-Ahmari A, Alkuraya H, Almehaidib A, Abanemai M, Alsohaibaini F, Alsaud B, Arnaout R, Abdel-Salam GMH, Aldhekri H, AlKhater S, Alqadi K, Alsabban E, Alshareef T, Awartani K, Banjar H, Alsahan N, Abosoudah I, Alashwal A, Aldekhail W, Alhajjar S, Al-Mayouf S, Alsemari A, Alshuaibi W, Altala S, Altalhi A, Baz S, Hamad M, Abalkhail T, Alenazi B, Alkaff A, Almohareb F, Al Mutairi F, Alsaleh M, Alsonbul A, Alzelaye S, Bahzad S, Bin MA, Jarrad O, Meriki N, Albeirouti B, Alqasmi A, AlBalwi M, Makhseed N, Hassan S, Salih I, Salih MA, Shaheen M, Sermin S, Shahrukh S, Hashmi S, Shawli A, Tajuddin A, Tamim A, Alnahari A, Ghemlas I, Hussein M, Wali S, Murad H, Meyer BF, Alkuraya FS (2019) Lessons learned from large-scale, first-tier clinical exome sequencing in a highly consanguineous population. Am J Hum Genet 104:1182-1201. https://doi.org/10.1016/j. ajhg.2019.04.011

Publisher's Note Springer Nature remains neutral with regard to jurisdictional claims in published maps and institutional affiliations. 